\title{
Analytical and Experimental Investigation on Wear Performance of Disc Brake Pad
}

\author{
V.A. Kalhapure ${ }^{\text {a,* }}$, H.P. Khairnar a \\ a Department of Mechanical Engineering, VJTI, Mumbai, India.
}

Keywords:

Wear Behavior

Coefficient of Friction

Winkler Model

Sliding Speed

Interface Temperature

Friction Test Rig

* Corresponding author:

Vaibhav A. Kalhapure

Email: vakalhapure90@gmail.com

Received: 21 February 2020

Revised: 6 April 2020

Accepted: 7 May 2020

\begin{abstract}
A B S T R A C T
Automotive disc brake pads are subjected to different wear situations under variable operating conditions; industry needs to evolve the methodology to estimate wear rate of brake pads to address the issue of extreme brake fading. In the present investigation friction and wear behavior of different brake pads is tested on newly developed test rig under dry sliding conditions. The analytical model is proposed to simulate different operating conditions using Winkler differential and integral relation. The infrared thermal images at the interface of the brake pad and disc were obtained to analyze the temperature variations under different operating conditions. The results showed the correlation of the load (20 N-80 N) and speed (300 rpm-1100 rpm) with temperature at the interface between pad and disc varies from $97.80 \mathrm{C}$ to $306.70 \mathrm{C}$, which is moderate rise. The coefficient of friction increases as load increases from 0.24 at $300 \mathrm{rpm}, 20 \mathrm{~N}$ load and maximum value 0.64 at $1000 \mathrm{rpm}, 60 \mathrm{~N}$ load. Temperature rise at higher load and speed having the major influence on changing the friction and wear behavior of pad friction material. There is a consistency between reported experimental observations and obtained values from the proposed the analytical model.
\end{abstract}

(C) 2020 Published by Faculty of Engineering

\section{INTRODUCTION}

Disc brakes had been widely used as a basic braking device in diverse commercial, transport vehicles and mechanical equipment's, which comprehend the role of the friction force generated through the brake pads sliding at the friction disc with an event or injury can be prevented by slowing down or stopping at a time. The motive of braking system is to transform a mechanical system's kinetic energy into the friction heat energy of the brake pad- disc friction interface. Heat dissipated from the surface interaction is exchange particularly with the surroundings and at some point of braking, temperature may additionally rise inside the contact areas. Wear behavior is highly dependent on the ingredients of the friction materials at the high temperatures, resulting from the braking conditions. These are must be chosen in order to ensure acceptable braking conditions causes high temperature stability, which decreases the wear level of friction material. 
Brake pads tend to be more sensitive to various parameters of braking, such as applied pressure, speed of vehicle, brake interface temperature and surrounding conditions. The brake pad materials are mostly made up of metallic, semimetallic, and non-metallic matrix of friction material $[1,2]$. The brake disc speed is high at working, which forms the debris by shearing action of friction material and some particles expelled out of the contact interface. The process of deformation, crushing, breaking and peeling of debris particles has been practices repeatedly and adhered to friction material to form surface film layer. The friction surface film layer has more influence on friction and wear behavior of brake system [3-5]. The friction film layer is made of primary plateaus of hard particles and fibers and secondary plateaus of piling up wear debris and compacted against the primary plateaus [6-9]. Friction, wear and emission performance were strongly affected by the creation of secondary plateaus of cermet-coated disc. During braking, the topography of the disc surface changes, resulting in changes in the padto-disc contact situation regarding pressure and contact area $[10,11]$. In the braking process, friction heat is always generated between brake friction pairs, and in effect has a great impact on the mechanical and physical properties of the friction material surface. Particularly, under intense braking conditions of high speed and overload, the friction surface temperature will rise rapidly to an extremely high value, and then disastrous friction anomalies will easily arise [12-15]. The difference between tribological properties of various commercial pad materials were compared with the help of pin-on-disc tribometer, flat-on-flat machine, puck-on-lining machine and block-on-ring machine test rig for different operating conditions under dry sliding condition [16-18]. Under normal operating conditions, the wear difference between materials was slightly differing from one type of test machine to another [19]. The control on involvement on third-bodies on contact zone and accurate choice of machine for wear testing had an important significance on wear quantity produced and ranking of wear rates between materials [20]. During all braking conditions, non-asbestos brake pad materials maintained stable coefficient of friction, while fluctuating in the case of asbestos and commercial brake pads and the wear rate of non-asbestos brake pads was in decreasing trend as compared to other two friction materials [21-25]. Actual field wear behavior of a heavy commercial vehicle (HCV) brake friction liner running over different terrain/traffic, load conditions were correlated with inertia brake dynamometer (IBD) test behavior. Deceleration and the resulting increase in temperature mainly led to wear, since all brake liners were manufactured using the same formulation [26]. The effect of binder on physical, mechanical, and tribological properties was investigated and analyzed using the industry standards JASO C-406 and JASO C427 based Inertia Brake Dynamometer (IBD). Thermogravimetric Analysis (TGA) tested thermal stability of the brake pad, and Scanning Electron Microscopy (SEM) analysis studied wear mechanism [27,28]. The tribological behavior of brake pad friction material was much influenced by means of thermal binding degradation and worn out at high level of temperatures due to the presence of carbonaceous products analyzed with the help of thermo-gravimetric analysis, Raman Spectroscopy and SEM coupled with EDXS [2931]. The EDS analysis become used to examine the chemical analysis of unused and worn out surfaces and the AFM technique respectively used to obtain the $3 \mathrm{D}$ roughness profiles of unused and worn out pads [22].

The ANSYS Multiphysics technique was used to analyze the thermal behavior of the dry contact between the brake pad discs during the braking process and the rotor's critical temperature by taking into account other parameters such as the material used, geometric configuration of the disk and the braking mode [32]. Many analytical and mathematical models that explain wear processes in different types of friction joints having different materials; under different operating conditions have yet come into being [33-36]. Archard was the first author proposed a linear wear model for metals [37]. Rhee suggested a non-linear wear model for friction material of brakes [38]. The relationships were developed for the coefficient of friction under the state of equilibrium using principles of classical mechanics with friction considering the variations of longitudinal forces [39]. The frictional behavior of the drum and disc brakes was analyzed and the relationships were derived on the piston side as well as on the non-piston side for friction coefficient with varying parameter conditions; longitudinal force, caliper 
force and torque [40]. Chichinadze outlined the temperature model for various types of braking systems. The contact temperature rise was the sum of average temperature of nominal contact area due to heat flux and flash temperature equally distributed on contact surface $[11,41]$. However, a general analytical model has not been proposed so far which sufficiently describes any issues related to the rate of wear in brake pad friction surface.

The current study aims to determine and investigate the friction and wear behavior of disc brake system using newly developed test rig under different operating conditions (sliding speed, load, sliding distance and interface temperature). The developed test rig used to conduct the friction and wear test under different loads (20-80 N), variable speed (300-1100 rpm) and constant sliding distance $(1000 \mathrm{~m})$. An analytical model is proposed to account for the wear rate predictions of brake pad friction material. Broad agreement is shown between the analytical model and experimental observations.

\section{DISC BRAKE WEAR MODEL AT INTERFACE}

The functionality of disc brake system is strongly depends on the pad and disc contact interface at different operating conditions. The performance of system is varying due to the effect of contact area, applied pressure, sliding speed, interface temperature and sliding distance.

\section{i) Friction Contact Area:}

Friction contact between the braking surfaces occurs in the region $r \in$ (ri, ro). The pad friction materials are pressed with an axial force $F(t)$ as shown Fig. 1. The contact pressure between pad and disc at any contact point in radial circumference and time is $P(r, t)$. The disc is rotating with relative angular velocity with time $\omega(t)$ and the wear coefficient of frictional material depends on the variation in temperature with time and radial distance $T(r$, t) in a particular contact point is represented by $\mathrm{K}_{(\mathrm{w})}$. $(\mathrm{T}(\mathrm{r}, \mathrm{t})$ ) respectively. The coefficient of resilience in axial direction of pad friction material is indicated by $\mathrm{k}$. The elastic contact interaction occurs between friction lining and disc is satisfied by 'Winkler' relation. The modelling wear process of clutch friction linings the general nonlinear differential model of wear has been used, governed by $[42,43]$ :

$$
\frac{\partial U_{(w)}(\mathrm{r}, \mathrm{t})}{\partial t}=K_{(w)}(T(r, t)) \cdot|\omega(t)|^{\beta 1} \cdot r^{\beta 2} \cdot P^{\alpha 1}(r, t)
$$

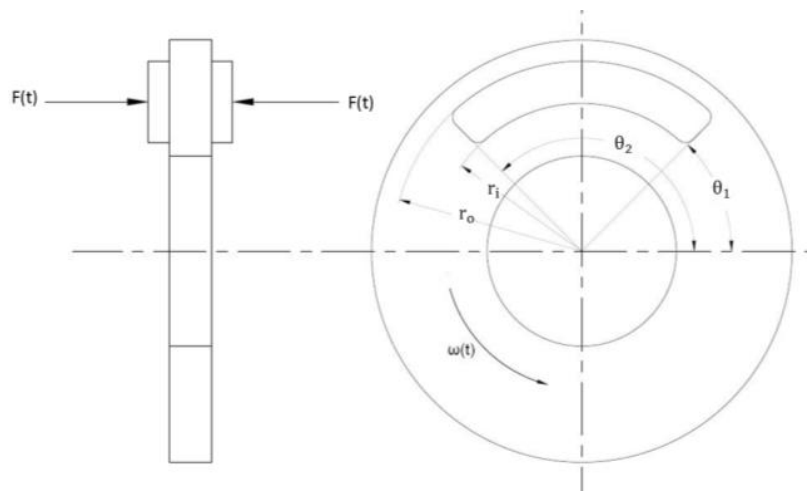

Fig. 1. Simplified model of the disc brake.

The integral wear model for the friction lining in the region of radial distance $r$ and a particular case taking into account of the hereditary model, the total wear over a time $t$ from all earlier perturbations at instance of time $t^{\prime}$ have the form $[44,45]$ :

$$
U_{(w)}(\mathrm{r}, \mathrm{t})=\int_{0}^{t} K_{(w)}\left(T\left(r, t^{\prime}\right)\right)\left|\omega\left(t^{\prime}\right)\right| \cdot r \cdot K \cdot\left(t, t^{\prime}\right) \cdot P\left(r, t^{\prime}\right) d t^{\prime}
$$

The contact conditions of the friction linings in the disc brake interface point be:

$$
U(r, t)+U_{(w)}(\mathrm{r}, \mathrm{t})=\mathrm{E}(\mathrm{t})
$$

Differentiation of equation (3) w.r.t time t,

$$
\frac{\partial \mathrm{U}(\mathrm{r}, \mathrm{t})}{\partial \mathrm{t}}+\frac{\partial U_{(w)}(\mathrm{r}, \mathrm{t})}{\partial \mathrm{t}}=\frac{\mathrm{dE}(\mathrm{t})}{\mathrm{dt}}
$$

Where, $E(t)$ be the function describing the decrease the distance between pad friction lining and disc. Taking into account equation (4) yields,

$$
\begin{aligned}
& k \frac{\partial P(r, t)}{\partial t}+K_{(w)}(T(r, t)) \cdot|\omega(t)|^{\beta 1} \cdot r^{\beta 2} \cdot P^{\alpha 1}(r, t) \\
& =\frac{\mathrm{dE}(\mathrm{t})}{\mathrm{dt}}
\end{aligned}
$$

Equation (5) describes the differential wear model in the form of change in distance between the disc and pad contact surface. Similarly, the 
below model defines the change in contact area in the integral form,

$$
\begin{aligned}
& k P(r, t)+\int_{0}^{t} K_{(w)}\left(T\left(r, t^{\prime}\right)\right)\left|\omega\left(t^{\prime}\right)\right| \cdot r \cdot K \cdot\left(t, t^{\prime}\right) \cdot P\left(r, t^{\prime}\right) d t^{\prime} \\
& =\mathrm{E}(\mathrm{t})
\end{aligned}
$$

equation (5) and (6) multiply by r. dr and integrating in the radial region of friction surface $r \in(\mathrm{ri}, \mathrm{ro})$, the relation of differential wear model becomes,

$$
\begin{aligned}
& \int_{r_{i}}^{r_{o}} K \frac{\partial P(r, t)}{\partial t} r \cdot d r+\int_{r_{i}}^{r_{o}} K_{(w)}(T(r, t)) \cdot|\omega(t)|^{\beta 1} \cdot r^{\beta 2} \cdot P^{\alpha 1}(r, t) r d r \\
& =\int_{r_{i}}^{r_{i}} \frac{\mathrm{dE}(\mathrm{t})}{\mathrm{dt}} r d r
\end{aligned}
$$

Similarly the integral wear model becomes,

$$
\begin{aligned}
& \int_{r_{i}}^{r_{o}} K P(r, t) r d r+ \\
& \int_{r_{i}}^{r_{o}}\left(\int_{0}^{t} K_{(w)}\left(T\left(r, t^{\prime}\right)\right)\left|\omega\left(t^{\prime}\right)\right| \cdot r \cdot K \cdot\left(t, t^{\prime}\right) \cdot P\left(r, t^{\prime}\right) d t^{\prime}\right) r d r \\
& =\int_{r_{i}}^{r_{o}} \mathrm{E}(\mathrm{t}) \mathrm{r} \cdot \mathrm{dr}
\end{aligned}
$$

\section{ii) Contact Force:}

The geometry of annular brake pad contact area is shown in Fig. 1 and the pad pressed against the disc with a force of $F(t)$ in axial direction. The application of force is changes with time at the surface contact area of pad measured by $\theta_{1} \& \theta_{2}$ angles, the force of pad is:

$$
F(t)=\left(\theta_{2}-\theta_{1}\right) \int_{r_{i}}^{r_{o}} \mathrm{r} \cdot \mathrm{P}(\mathrm{r}, \mathrm{t}) \mathrm{dr}
$$

Differentiating and rearranging of equation (9) w.r.t. time $t$,

$$
\frac{\partial \mathrm{P}}{\partial \mathrm{t}}(\mathrm{r}, \mathrm{t})=\frac{2}{\left(r_{o}^{2}-r_{i}^{2}\right)\left(\theta_{2}-\theta_{1}\right)} \frac{\mathrm{dF}(\mathrm{t})}{\mathrm{dt}}
$$

Taking equation (10) in equation (7):

$$
\begin{aligned}
& \frac{2 k}{\left(r_{o}^{2}-r_{i}^{2}\right)\left(\theta_{2}-\theta_{1}\right)} \cdot \frac{\mathrm{dF}(\mathrm{t})}{\mathrm{dt}}+ \\
& \frac{2}{\left(r_{o}^{2}-r_{i}^{2}\right)}|\omega(t)|^{\beta 1} \int_{r_{i}}^{r_{o}} K_{(w)}(T(r, t)) \cdot r^{1+\beta 1} \cdot P^{\alpha 1}(r, t) d r \\
& =\frac{\mathrm{dE}(\mathrm{t})}{\mathrm{dt}}
\end{aligned}
$$

Similarly taking equation (10) in equation (8), In case of an integral wear model, after sufficient transformations,

$$
\begin{aligned}
& \frac{2 k \cdot F(t)}{\left(\theta_{2}-\theta_{1}\right)\left(r_{o}^{2}-r_{i}^{2}\right)}+ \\
& \frac{2}{\left(r_{o}^{2}-r_{i}^{2}\right)} \int_{r_{i}}^{r_{o}}\left(\int_{0}^{t} K_{(w)}\left(T\left(r, t^{\prime}\right)\right)\left|\omega\left(t^{\prime}\right)\right| \cdot K \cdot\left(t, t^{\prime}\right) \cdot P\left(r, t^{\prime}\right) d t^{\prime}\right) . \\
& r^{2} d r=\mathrm{E}(\mathrm{t})
\end{aligned}
$$

Comparing relations (5) \& (11)

$$
\begin{aligned}
& K_{(w)}(T(r, t)) \cdot|\omega(t)|^{\beta 1} \cdot r^{\beta 2} \cdot P^{\alpha 1}(r, t)+ \\
& k \frac{\partial P(r, t)}{\partial t}=\frac{2 K}{\left(\theta_{2}-\theta_{1}\right) \cdot\left(r_{o}^{2}-r_{i}^{2}\right)} \frac{\mathrm{dF}(\mathrm{t})}{\mathrm{dt}}+ \\
& \frac{2}{\left(r_{o}^{2}-r_{i}^{2}\right)}|\omega(t)|^{\beta 1} \int_{r_{i}}^{r_{o}} K_{(w)}(T(r, t)) \cdot r^{1+\beta 1} \cdot P^{\alpha 1}(r, t) d r
\end{aligned}
$$

In turn, comparisons of relations (6) and (12) yields,

$$
\begin{aligned}
& \int_{0}^{t} K_{(w)}\left(T\left(r, t^{\prime}\right)\right)\left|\omega\left(t^{\prime}\right)\right| \cdot r \cdot K \cdot\left(t, t^{\prime}\right) \cdot \\
& P\left(r, t^{\prime}\right) d t^{\prime} \frac{2 k \cdot F(t)}{\left(\theta_{2}-\theta_{1}\right)\left(r_{o}^{2}-r_{i}^{2}\right)}+ \\
& \frac{2}{\left(r_{o}^{2}-r_{i}^{2}\right)} \int_{r_{i}}^{r_{r}}\left(\int_{0}^{t} K_{(w)}\left(T\left(r, t^{\prime}\right)\right)\left|\omega\left(t^{\prime}\right)\right| \cdot K \cdot\left(t, t^{\prime}\right) \cdot P\left(r, t^{\prime}\right) d t^{\prime}\right) r^{2} d r
\end{aligned}
$$

Changing the order of integration of equation (14) becomes,

$$
\begin{aligned}
& k P(r, t)+ \\
& \int_{0}^{t} K_{(w)}\left(T\left(r, t^{\prime}\right)\right)\left|\omega\left(t^{\prime}\right)\right| \cdot r \cdot K \cdot\left(t, t^{\prime}\right) \cdot P\left(r, t^{\prime}\right) d t^{\prime} \\
& \left.=\frac{2}{\left(r_{2}^{2}-r_{1}^{2}\right)} \int_{0}^{t} K \cdot\left(t, t^{\prime}\right) \cdot \mid \omega\left(t^{\prime}\right)\right)\left(\int_{t_{i}}^{r_{o}} K_{(w)}\left(T\left(r, t^{\prime}\right)\right) \cdot P\left(r, t^{\prime}\right) r^{2} d r d t^{\prime}\right) \\
& +\frac{2 K F(t)}{\left(\theta_{2}-\theta_{1}\right)\left(r_{2}^{2}-r_{1}^{2}\right)}
\end{aligned}
$$

At the initial instance of time $\mathrm{t}=0$, since the linear displacement due to wear $U_{(w)}=0$ and equation (3) becomes,

$$
E(0)=U(r, 0)=k \cdot P(r, 0)
$$

Also the equation (9) yields,

$$
F(0)=\left(\theta_{2}-\theta_{1}\right) \int_{r_{i}}^{r_{o}} r . P(r, 0) d r
$$


From equation (16) and (17):

$$
E(0)=k \frac{F(0)}{\left(\theta_{2}-\theta_{1}\right)} \times \frac{2}{\left(r_{o}^{2}-r_{i}^{2}\right)}
$$

The analogous relation presented below, that assumes the case of linear wear of contact material, Assume the $\alpha 1=1$ and $\beta 1=\beta 2=1$ at initial time $t=0$, the differential model in equation (1) becomes:

$$
\frac{\partial U_{(w)}(\mathrm{r}, 0)}{\partial t}=\frac{2 K_{(w)}(T(r, 0)) \cdot F \cdot|\omega|}{\left(\theta_{2}-\theta_{1}\right)\left(r_{0}^{2}-r_{i}^{2}\right)} \cdot r
$$

Similarly the relation yields in equation (11), decrease the distance between brake contact surface at initial time,

$$
\frac{4|\omega| \cdot K_{(w)} \cdot T_{0} \cdot\left(r_{o}^{3}-r_{i}^{3}\right) F(0)}{3\left(r_{o}^{2}-r_{i}^{2}\right)^{2}\left(\theta_{2}-\theta_{1}\right)}=\frac{\mathrm{dE}(0)}{\mathrm{dt}}
$$

The equations governing contact pressure calculations by taking above assumptions in equation (13):

$$
\begin{aligned}
& K_{(w)}(T(r, t)) \cdot|\omega(t)|^{\beta 1} \cdot r^{\beta 2} \cdot P^{\alpha 1}(r, t) \\
& +k \frac{\partial P(r, t)}{\partial t}=\frac{2 K}{\left(\theta_{2}-\theta_{1}\right)\left(r_{0}^{2}-r_{i}^{2}\right)} \frac{\mathrm{dF}(\mathrm{t})}{\mathrm{dt}} \\
& +\frac{2}{\left(r_{0}^{2}-r_{i}^{2}\right)}|\omega(t)|^{\beta 1} \int_{r_{i}}^{r_{o}} K_{(w)}(T(r, t)) \cdot r^{1+\beta 1} \cdot P^{\alpha 1}(r, t) d r \\
& K_{(w)}(T(r, t)) \cdot|\omega| \cdot r \cdot P(r, t)+k \frac{\partial P(r, t)}{\partial t} \\
& =\frac{2 K_{(w)}(T(r, t)) \cdot|\omega|}{\left(r_{o}{ }^{2}-r_{i}^{2}\right)} \int_{r_{i}}^{r_{o}} r^{2} \cdot P(r, t) d r
\end{aligned}
$$

Applying Laplace Transformation to the relation (21),

$$
\begin{aligned}
& K_{(w)}(T(r, t)) \cdot|\omega| \cdot r \cdot \bar{P}(r, s) \\
& +k s \bar{P}(r, s)-k P(r, 0) \\
& =\frac{2 K_{(w)}(T(r, t))|\omega|}{\left(r_{o}^{2}-r_{i}^{2}\right)} \int_{r_{i}}^{r_{o}} r^{2} \cdot \bar{P}(r, s) d r
\end{aligned}
$$

$$
\begin{aligned}
& \bar{P}(r, s)=\left[K_{(w)}(T(r, t))|\omega| . r+k s\right]^{-1} . \\
& \frac{2 . K_{(w)}(T(r, t))|\omega|}{\left(r_{o}{ }^{2}-r_{i}^{2}\right)} \int_{r_{i}}^{r_{o}} r^{2} \cdot \bar{P}(r, s) d r \\
& +\frac{2 K F}{\left(r_{o}{ }^{2}-r_{i}^{2}\right)^{2}\left(\theta_{2}-\theta_{1}\right)}
\end{aligned}
$$

Since,

$$
P(r, \infty)=\lim _{s \rightarrow 0} s \bar{P}(r, s)
$$

After the next Transformation of equation of (24) the below relation yields:

$$
P(r, \infty)=\frac{1}{r}\left(\frac{2}{\left(r_{o}^{2}-r_{i}^{2}\right)} \int_{r_{i}}^{r_{o}} r^{2} \cdot P(r, \infty) d r\right)
$$

The integral equation (25) has to follow the below form:

$$
P(r, \infty)=\frac{Z}{r}
$$

Equation (26) be the solution of equation (24):

$$
\begin{aligned}
& P(r, \infty)=\frac{1}{r}\left(\frac{2}{\left(r_{2}^{2}-r_{1}^{2}\right)} \int_{r_{i}}^{r_{o}} r^{2} \cdot \frac{A}{r} d r\right) \\
& P(r, \infty)=\frac{1}{r}\left(\frac{2 . A}{\left(r_{2}^{2}-r_{1}^{2}\right)} \int_{r_{i}}^{r_{o}} r \cdot d r\right)=\frac{A}{r}
\end{aligned}
$$

The constant $\mathrm{Z}$ can be determined by Putting above relation in (10) and taking variation in time at $\mathrm{t} \rightarrow \infty$ :

$$
\begin{gathered}
F=\left(\theta_{2}-\theta_{1}\right) \int_{r_{i}}^{r_{o}} \mathrm{r} \cdot \frac{Z}{r} \mathrm{dr} \\
Z=\frac{F}{\left(\theta_{2}-\theta_{1}\right) \cdot\left(r_{o}-r_{i}\right)}
\end{gathered}
$$

The contact pressure distribution at steady state in the form $P(r, \infty)$ becomes:

$$
P(r, \infty)=\frac{F}{\left(\theta_{2}-\theta_{1}\right) \cdot\left(r_{o}-r_{i}\right) r}
$$


The speed of wear in brake pad surface is constant on entire surface and wear of pad surface in each point of contact theoretically increase to infinity with constant speed wear. The rate of wear in disc and brake pad material contact interface at certain amount of time is given by the relation:

$$
\frac{\partial U_{(w)}}{\partial t}=\frac{K_{(w)} \cdot \Delta T \cdot|\omega| \cdot F}{\left(\theta_{2}-\theta_{1}\right) \cdot\left(r_{o}-r_{i}\right)}
$$

Equation (29) signifies the relation between different operating conditions viz. wear coefficient of friction material, change in temperature or temperature gradient, angular velocity, load, and area of friction material on wear rate of brake pad material with sliding time.

\section{EXPERIMENTAL INVESTIGATION}

\subsection{Newly Developed Disc Brake Pad Test Rig}

The schematic components developed in this study for the brake pad test are shown in Fig. 2, including the general setup to assess wear and friction behavior. The tester consists of 21 components and has been constructed according to the real friction and wear behavior affected by brake pad interaction with an automotive rotor disc. In this test rig, a hydraulic unit with proportional valves guides the oil fluid which governs the movements of the brake pads on opposite sides of the rotor disc with aid of piston.

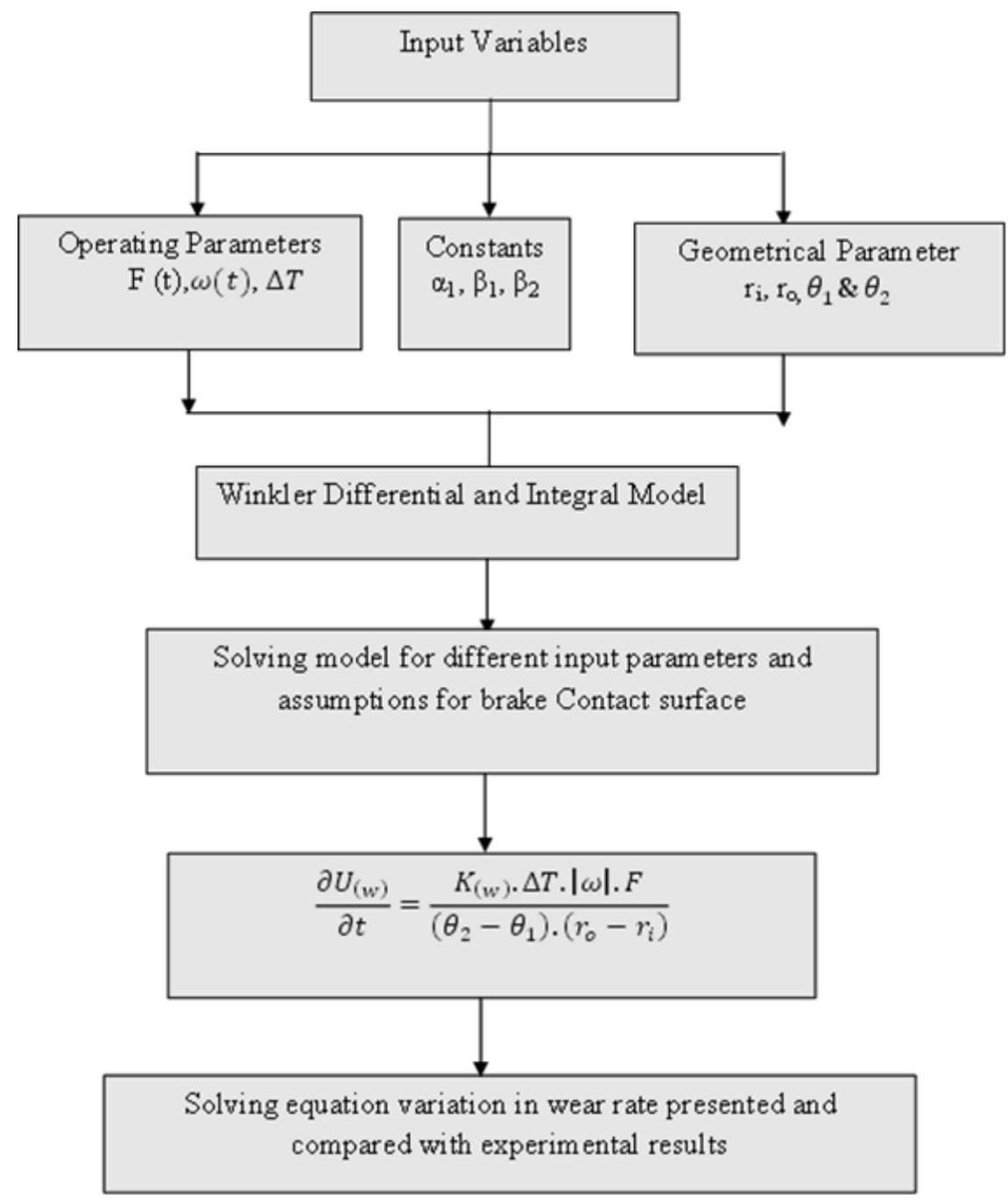

Fig. 2. Algorithm for Wear Rate Estimation. 


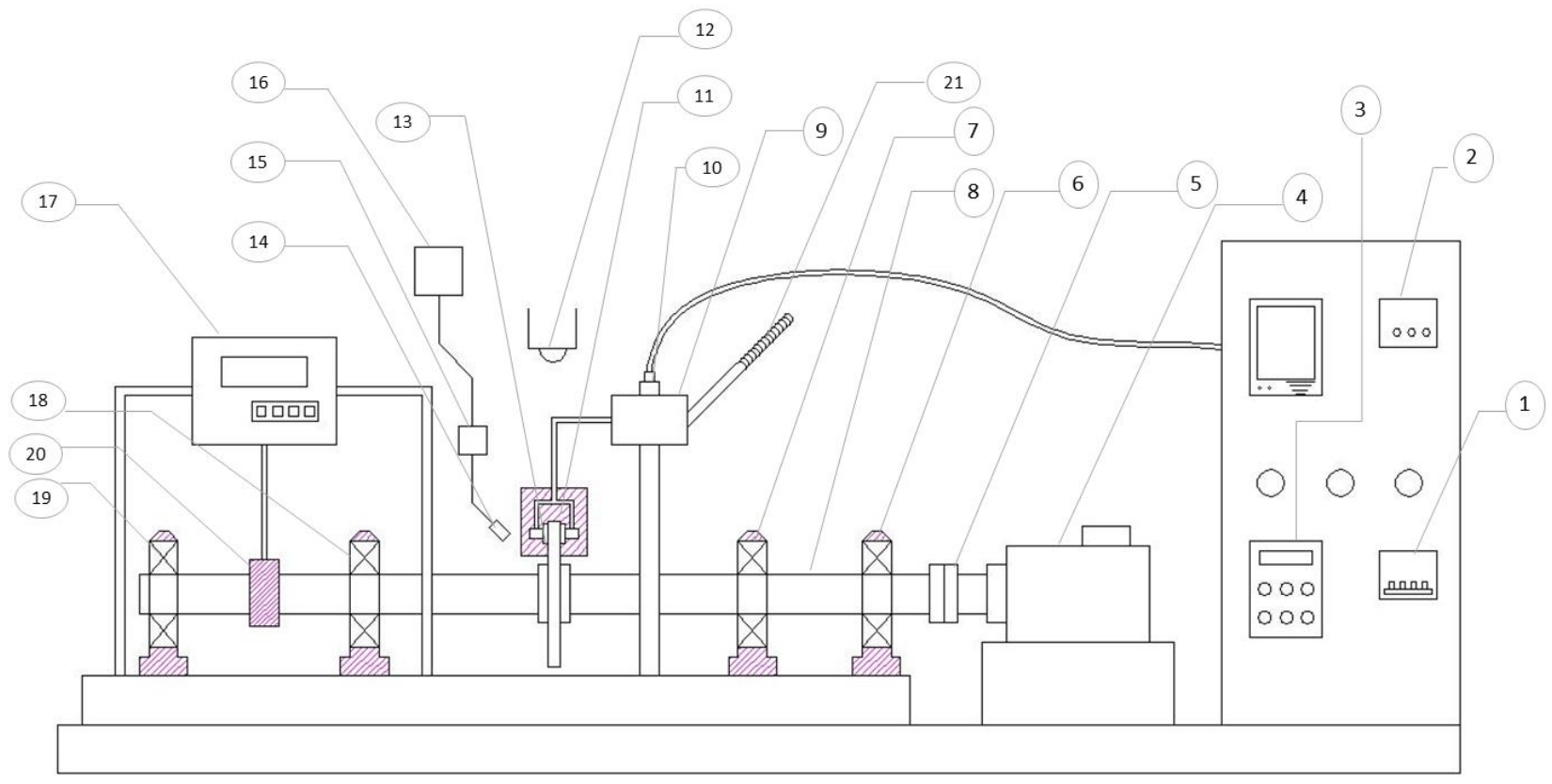

Fig. 3. Schematic Diagram of Developed Test Rig (1) Power Supply, (2) Pressure Display, (3) Variable Frequency Drive (VFD), (4) AC motor-3.7 kW, (5) Coupling, (6) (7) (18) (19) Bearings, (8) Main Shaft, (9) Hydraulic Oil Reservoir (10) Pressure Sensor, (11) Brake Calliper, (12) Infrared Camera, (13) Brake pads and Disc Mounting Unit, (14) Infrared Temperature Sensor, (15) Data Acquisition System (DAQ), (16) Computer Display, (17) Load Cell, (20) Loading Arrangement, (21) Lever.

An electric powered motor (1440 rpm, 3.7 $\mathrm{kW}$ ) is used to transmit its motion to the rotor disc through coupled shaft and the velocity of motor is varied by using VFD. The main shaft of $31.5 \mathrm{~mm}$ in diameter is attached to the motor and the bearings used to guide the main shaft through the axis of the rotor disc. The grey cast iron disc is having $250 \mathrm{~mm}$ diameter and the calliper action to decrease the speed and stop the wheels.

Load cell is installed on the frame sporting the calliper pad assembly and a positive pressure sensor are mounted the hydraulic unit to measure the output pressure. Moreover, the rotor disc and interface temperature is accurately measured by a non-contact infrared sensor made to measure the temperature of the brake pad. The analog output from sensor signal is suitably conditioned and fed to the computer using Nvis 632ic8 data acquisition system to measure and control the temperature at brake interface. Infrared thermal camera is used to measure and monitor the disc surface temperature and discpad interface temperature with the help of thermal images. The commercial automotive NAO brake pads are used for study the friction and wear behaviour. The values of the sliding speed, load, sliding distance and time are selected and combined each other to form several different braking conditions as shown in Table.1. The tester is also aimed, designed and built in such a way that compactness and easy replication would promote it's assemble and disassemble conditions.

\subsection{Test Procedure}

The newly test rig was used to investigate the pad friction material behavior at high speed (upto $1100 \mathrm{rpm}$ ) and moderate load (upto $80 \mathrm{~N}$ ) and constant sliding distance (1000 rpm).

Wear test was started at ambient temperature and humidity under dry condition with constant speed (300 rpm) and loads were varied from 20 $\mathrm{N}-80 \mathrm{~N}$ for constant sliding distance. The experimental procedure was repeated for different sliding speeds upto $1100 \mathrm{rpm}$ and the combinations of different testing parameters were presented in Table.1. The thermal camera and infrared sensor was used to measure the temperature correctly from the disc-pad interface. Variations in pressure at the braking pads were assessed with the aid of pressure transducer. The wear of the brake pad friction material was quantified through the digital vernier calliper by measuring the distance between disc and pad contact. 
Table. 1. Braking parameters and their testing values.

\begin{tabular}{|c|c|c|c|c|}
\hline $\begin{array}{c}\text { Load } \\
\text { (N) }\end{array}$ & $\begin{array}{c}\text { Sliding } \\
\text { Speed } \\
\text { (rpm) }\end{array}$ & $\begin{array}{c}\text { Sliding } \\
\text { Distance } \\
\text { (m) }\end{array}$ & $\begin{array}{l}\text { Time } \\
\text { (min) }\end{array}$ & Condition \\
\hline 20 & 300 & 1000 & 5 & \multirow{4}{*}{$\begin{array}{l}\text { Dry sliding with } \\
\text { ambient } \\
\text { temperature } \\
\text { and humidity }\end{array}$} \\
\hline 40 & 300 & 1000 & 5 & \\
\hline 60 & 300 & 1000 & 5 & \\
\hline 80 & 300 & 1000 & 5 & \\
\hline 20 & 400 & 1000 & 4 & \multirow{4}{*}{$\begin{array}{l}\text { Dry sliding with } \\
\text { ambient } \\
\text { temperature } \\
\text { and humidity }\end{array}$} \\
\hline 40 & 400 & 1000 & 4 & \\
\hline 60 & 400 & 1000 & 4 & \\
\hline 80 & 400 & 1000 & 4 & \\
\hline 20 & 500 & 1000 & 3 & \multirow{4}{*}{$\begin{array}{l}\text { Dry sliding with } \\
\text { ambient } \\
\text { temperature } \\
\text { and humidity }\end{array}$} \\
\hline 40 & 500 & 1000 & 3 & \\
\hline 60 & 500 & 1000 & 3 & \\
\hline 80 & 500 & 1000 & 3 & \\
\hline 20 & 600 & 1000 & 2 & \multirow{4}{*}{$\begin{array}{l}\text { Dry sliding with } \\
\text { ambient } \\
\text { temperature } \\
\text { and humidity }\end{array}$} \\
\hline 40 & 600 & 1000 & 2 & \\
\hline 60 & 600 & 1000 & 2 & \\
\hline 80 & 600 & 1000 & 2 & \\
\hline 20 & 700 & 1000 & 2 & \multirow{4}{*}{$\begin{array}{l}\text { Dry sliding with } \\
\text { ambient } \\
\text { temperature } \\
\text { and humidity }\end{array}$} \\
\hline 40 & 700 & 1000 & 2 & \\
\hline 60 & 700 & 1000 & 2 & \\
\hline 80 & 700 & 1000 & 2 & \\
\hline 20 & 800 & 1000 & 2 & \multirow{4}{*}{$\begin{array}{l}\text { Dry sliding with } \\
\text { ambient } \\
\text { temperature } \\
\text { and humidity }\end{array}$} \\
\hline 40 & 800 & 1000 & 2 & \\
\hline 60 & 800 & 1000 & 2 & \\
\hline 80 & 800 & 1000 & 2 & \\
\hline 20 & 900 & 1000 & 2 & \multirow{4}{*}{$\begin{array}{l}\text { Dry sliding with } \\
\text { ambient } \\
\text { temperature } \\
\text { and humidity }\end{array}$} \\
\hline 40 & 900 & 1000 & 2 & \\
\hline 60 & 900 & 1000 & 2 & \\
\hline 80 & 900 & 1000 & 2 & \\
\hline 20 & 1000 & 1000 & 1 & \multirow{4}{*}{$\begin{array}{l}\text { Dry sliding with } \\
\text { ambient } \\
\text { temperature } \\
\text { and humidity }\end{array}$} \\
\hline 40 & 1000 & 1000 & 1 & \\
\hline 60 & 1000 & 1000 & 1 & \\
\hline 80 & 1000 & 1000 & 1 & \\
\hline 20 & 1100 & 1000 & 1 & \multirow{4}{*}{$\begin{array}{l}\text { Dry sliding with } \\
\text { ambient } \\
\text { temperature } \\
\text { and humidity }\end{array}$} \\
\hline 40 & 1100 & 1000 & 1 & \\
\hline 60 & 1100 & 1000 & 1 & \\
\hline 80 & 1100 & 1000 & 1 & \\
\hline
\end{tabular}

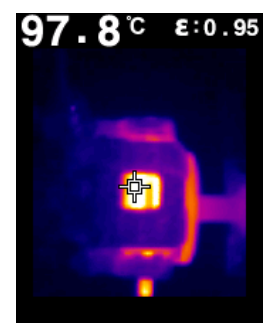

a) Interface temp. at $300 \mathrm{rpm}$

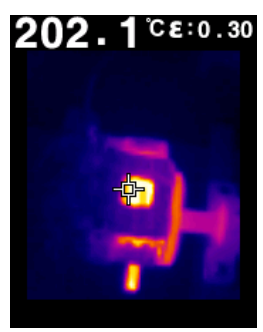

g) Interface temp. at $600 \mathrm{rpm}$

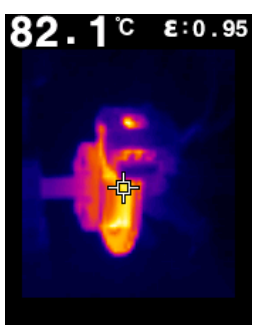

b) Disc Surface temp. at 300

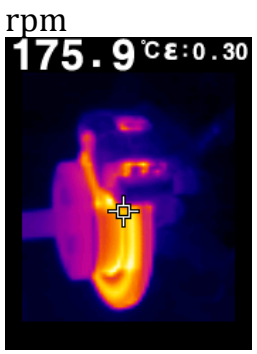

h) Disc Surface temp. at 600

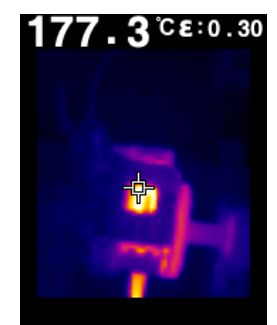

c) Interface temp. at 400

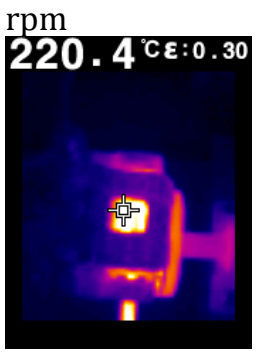

i) Interface temp. at 700

\subsection{Experimental Estimation of Wear Performance}

The frictional material wear can directly affect the safety and braking performance. Wear rate (W) of brake pad material is calculated by the linear thickness variation of pad samples using the formula [46]:

$$
W=\frac{V}{t}
$$

Where, $\mathrm{W}$ be the wear rate of brake pads $(\mathrm{m} / \mathrm{s})$; $\mathrm{V}$ be the material volume loss of pad material in $\left(\mathrm{m}^{3}\right)$ and $\mathrm{t}$ is the braking time in (s) resp.

\section{RESULTS AND DISCUSSION}

The wear rate under different operating conditions of brake was tested and experimental results are presented in Figs. 4-9 respectively. The brake pads were tested at different loads $(20$ $\mathrm{N}$ to $80 \mathrm{~N}$ ), variable sliding speeds (300 rpm to $1100 \mathrm{rpm})$, different temperature change or temperature gradient $(\Delta \mathrm{T})$ and constant sliding distance of $1000 \mathrm{~m}$. The effect of operating conditions on brake pad-disc interface and disc surface are shown by infrared thermal images in Fig. 4. The temperature at interface between pad and disc is varies from $97.8{ }^{\circ} \mathrm{C}$ to $306.7{ }^{\circ} \mathrm{C}$ as the speed varies from $300 \mathrm{rpm}$ to $1100 \mathrm{rpm}$ and load from $20 \mathrm{~N}$ to $80 \mathrm{~N}$, similarly the disc surface temperature changes from $82.1{ }^{\circ} \mathrm{C}$ to $296.4{ }^{\circ} \mathrm{C}$ for the same braking conditions.

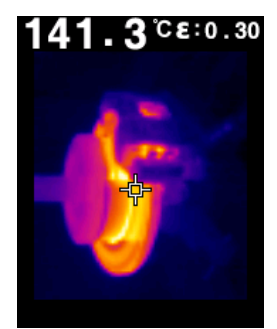

d) Disc Surface temp. at 400 rpm

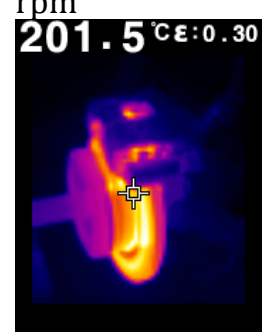

j) Disc Surface temp. at 700

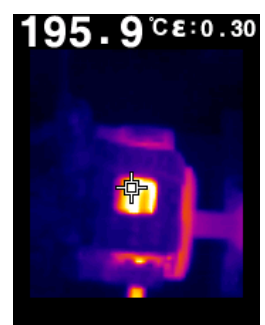

e) Interface temp. at 500 rpm

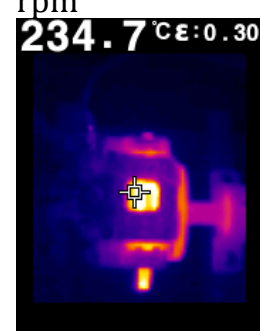

k) Interface temp. at 800

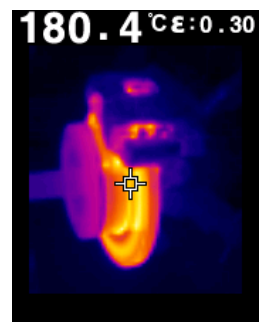

f) Disc Surface temp. at 500 rpm

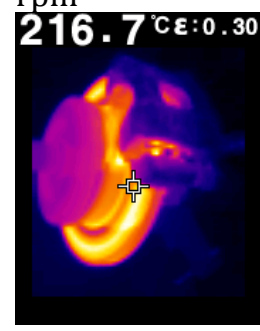

l) Disc Surface temp. at 800 


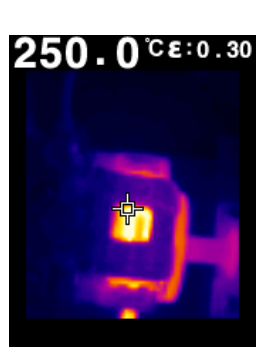

m) Interface temp. at $900 \mathrm{rpm}$

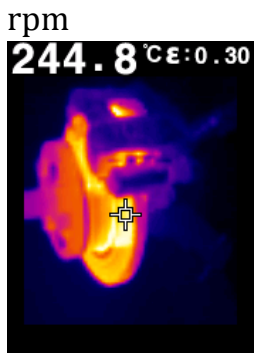

n) Disc Surface temp. at 900 rpm

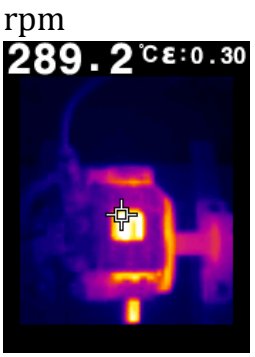

o) Interface temp. at 1000 rpm

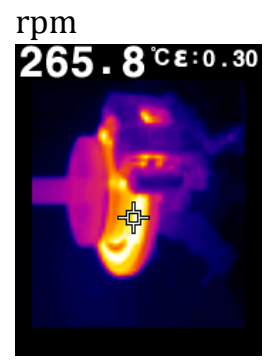

p) Disc Surface temp. at 1000 rpm

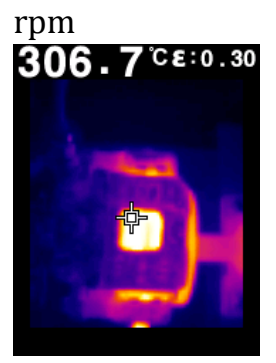

q) Interface temp. at 1100 rpm

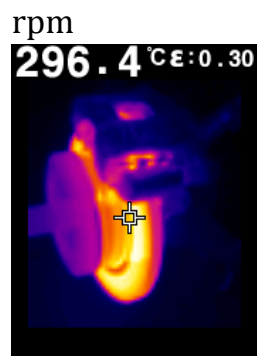

r) Disc Surface temp. at 1100 rpm

Fig. 4. Infrared Thermal Images of Brake System for Different Speeds (300-1100 rpm) at -i) Pad and Disc Interface and ii) Disc Surface.

\subsection{Influence of load on coefficient of friction at different sliding speeds}

The effect of load on frictional behavior of pad friction material is tested under different sliding speeds at dry condition presented in Fig. 5. Commonly, an increasing trend is detected for friction profile of the brake pad material with increasing load for different speeds.

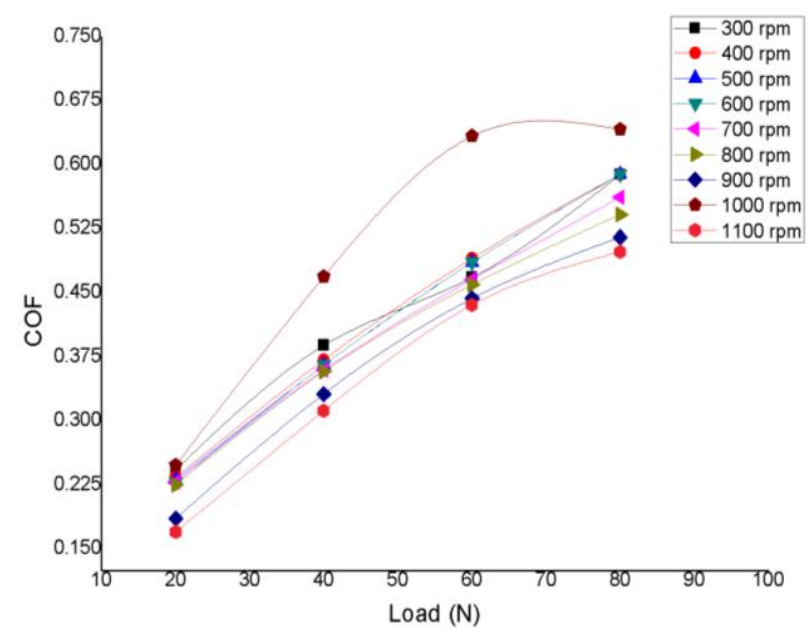

Fig. 5. Coefficient of friction with load for different sliding speeds.

At $300 \mathrm{rpm}$, with increase in load the coefficient of friction increases due to slow friction film formation at the contact interface of surface. The value of coefficient of friction varies from 0.24 to 0.54. Similar trend of rise in friction coefficient addressed in the Figure up to $700 \mathrm{rpm}$ as load increases. The distributed asperity are deformed and fragmented to form wear debris, which formulates the friction film. This friction film is increases the friction resistance strength and it results in increase in friction coefficient. The maximum value of coefficient of friction is 0.64 at $1000 \mathrm{rpm}$. The increase in friction coefficient is linear in trend because of uniform formation of transfer film at disc pad interface.

\subsection{Influence of load on wear rate of braking surface at constant sliding speed}

The load affects the wear through the deformation and size of interface contact between brake surfaces. Figures $6 a-6 i$ shows the typical variations in measured and theoretical wear rate and temperature gradient with load (20-80 N) at constant sliding speed for brake pad friction material tested under dry braking conditions on developed test rig. With the rising load the number and size of the contact point will increase i.e. $20 \mathrm{~N}$ to $80 \mathrm{~N}$ due to elastic-plastic contact. The wear rate for the friction brake pad material showed a non-linear growing trend towards increased load from $20 \mathrm{~N}$ to $80 \mathrm{~N}$ at 300 rpm sliding speed, due to significant rise in interface temperature shown in Fig. 6a. The rise in temperature causes metal matrix becomes unstable and the asperities scattered on the contact interface are warped and broken to form some debris up to $60 \mathrm{~N}$ load. After $60 \mathrm{~N}$, the debris is simply staved out to form loose granular films or friction film formation to increase the actual surface contact area. The increase in contact area is strengthened the friction and wear resistance. The trend of rise in wear rate is slightly linear at $400 \mathrm{rpm}$ and 500 rpm as the load change as indicates in Figs. 6b and 6c. Again, at $600 \mathrm{rpm}$ and $700 \mathrm{rpm}$ the wear rate is non-linearly increasing due to rise in interface temperature, which increases the debris formation, embedment, stacking and filling into the worn surface of friction material to generate more number of films as indicated in Figs. 6d and 6e. At $800 \mathrm{rpm}$ and $900 \mathrm{rpm}$, the wear rate is linear in nature and similar to 
theoretical wear rate values shown in Figs. $6 \mathrm{f}$ and $6 \mathrm{~g}$. The film formulated at interface acts as lubrication film, which reduces the heat generation and significant temperature rise takes place. The wear rate keeps increasing with the increasing loads, which causes the gradual rise in temperature. The temperature rise exhibits more heat at high loads and higher speeds, which reduces the matrix materials strength. Thus, the maximum wear occurs at higher loads and higher speed shown in Figs. $6 \mathrm{~h}$ and $6 \mathrm{i}$. This reduced the potential for third-body contact between the sliding surfaces and thus decreased wear resistance, which could subsidize the high material removal from the brake pad due to wear.

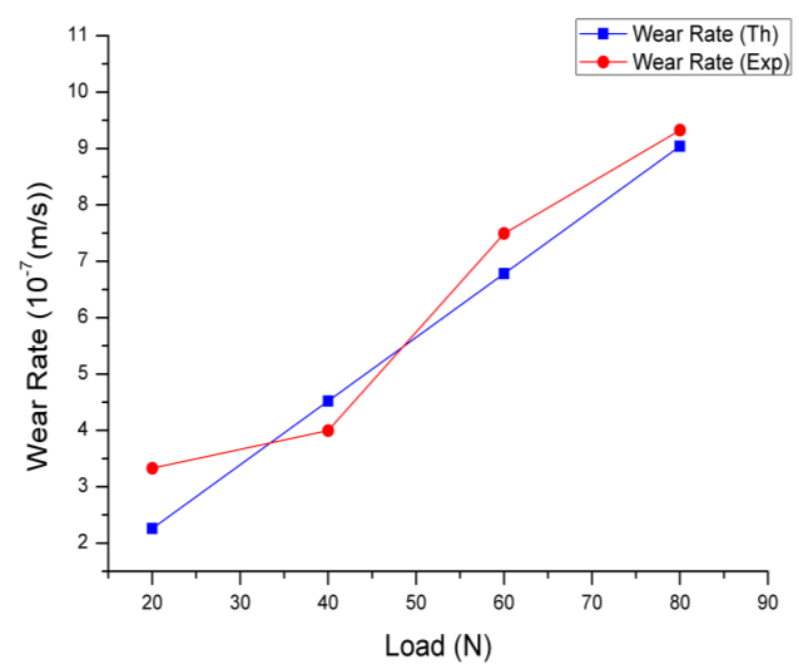

(a) $300 \mathrm{rpm}$

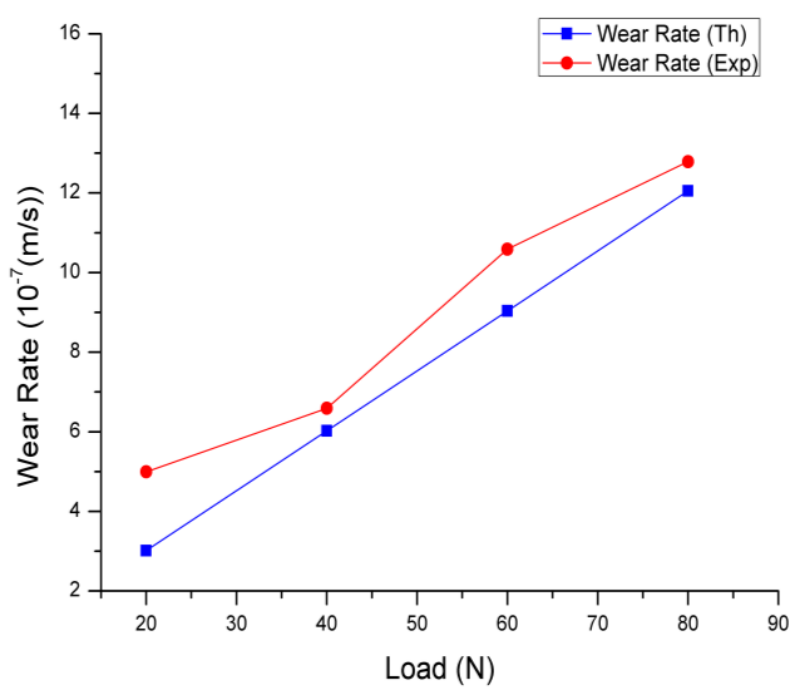

(b) $400 \mathrm{rpm}$

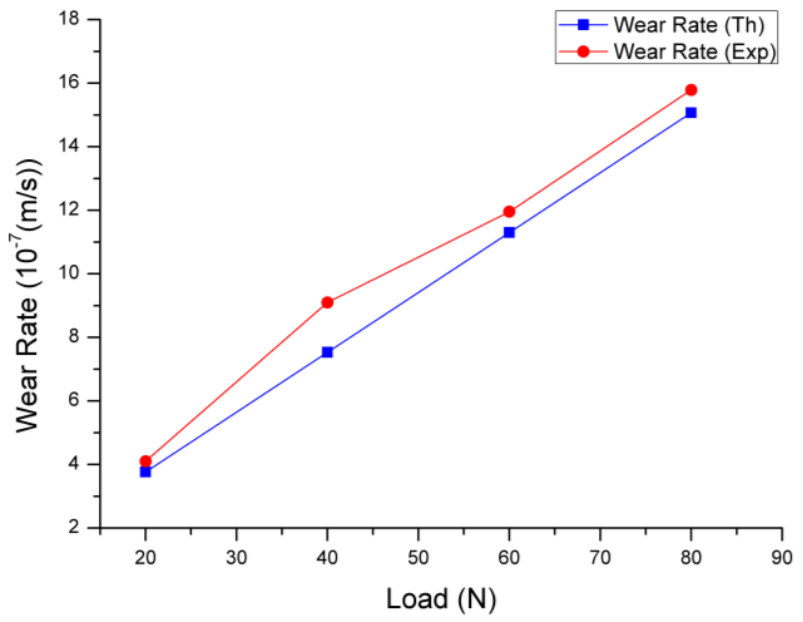

(c) $500 \mathrm{rpm}$

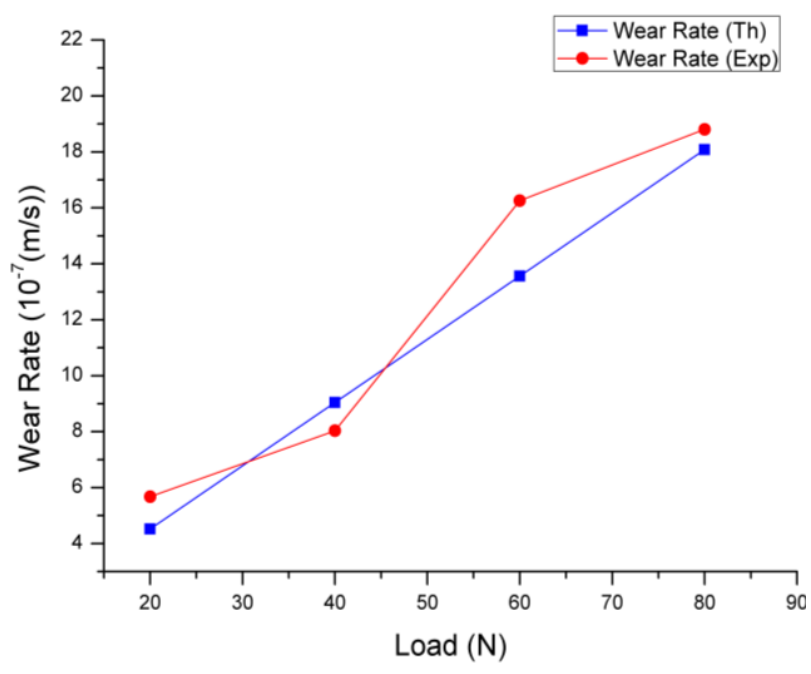

(d) $600 \mathrm{rpm}$

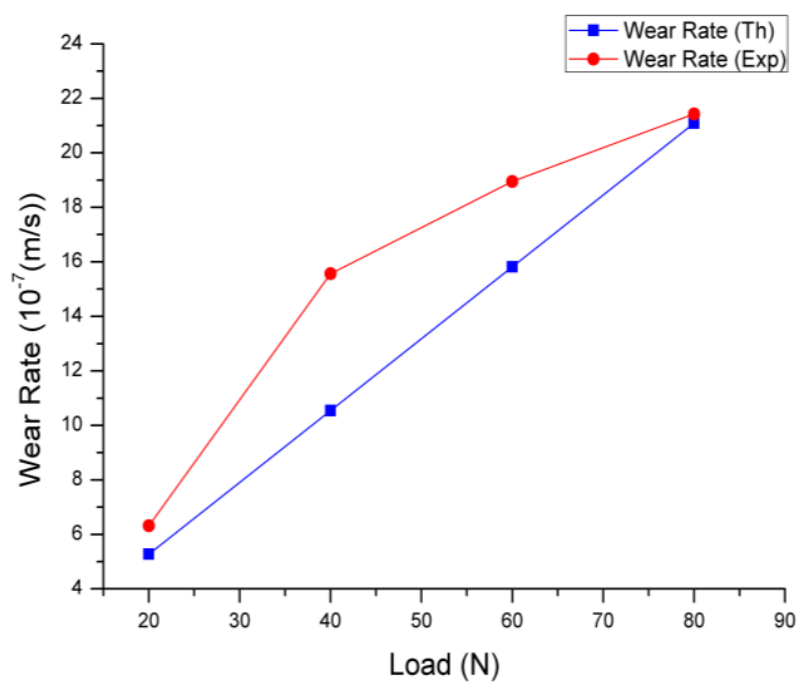

(e) $700 \mathrm{rpm}$ 


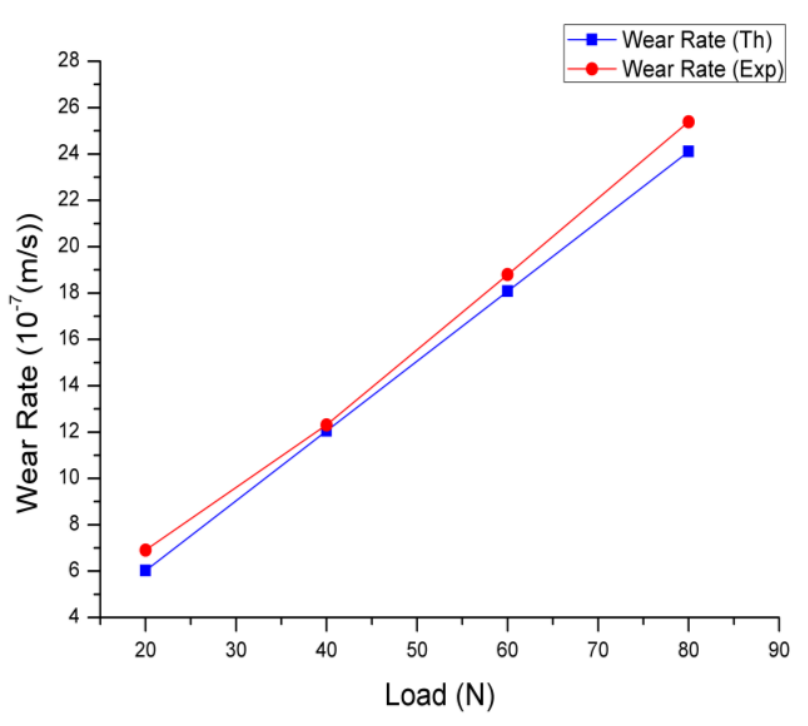

(f) $800 \mathrm{rpm}$

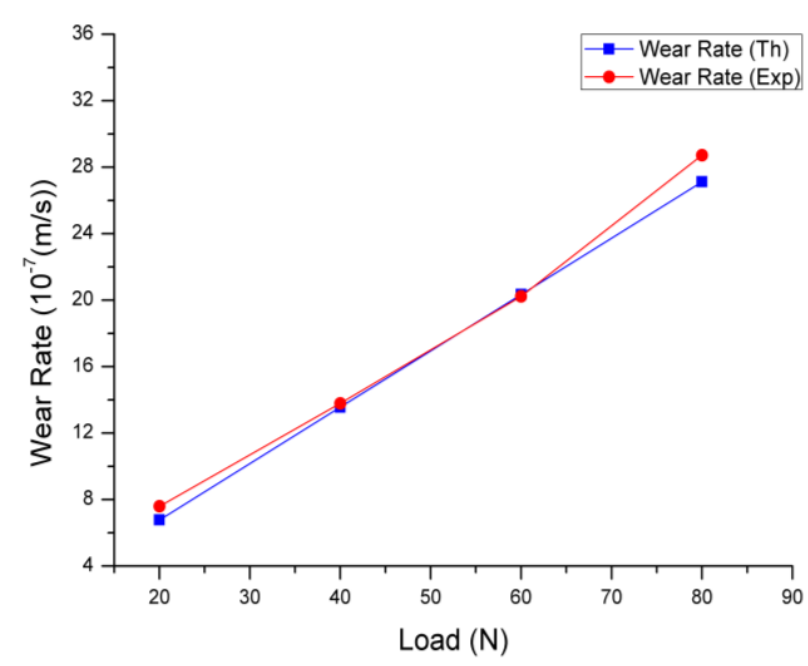

(g) $900 \mathrm{rpm}$

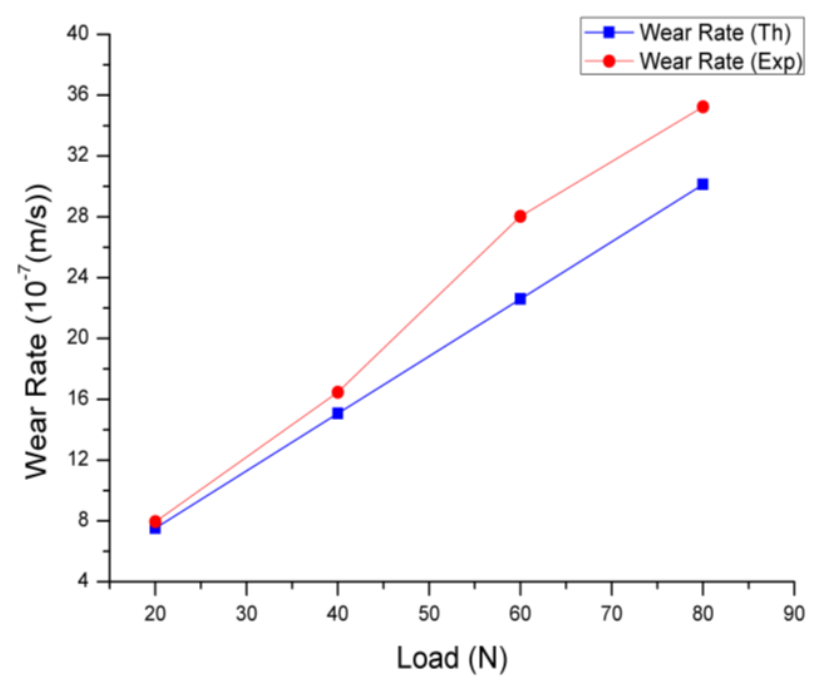

(h) $1000 \mathrm{rpm}$

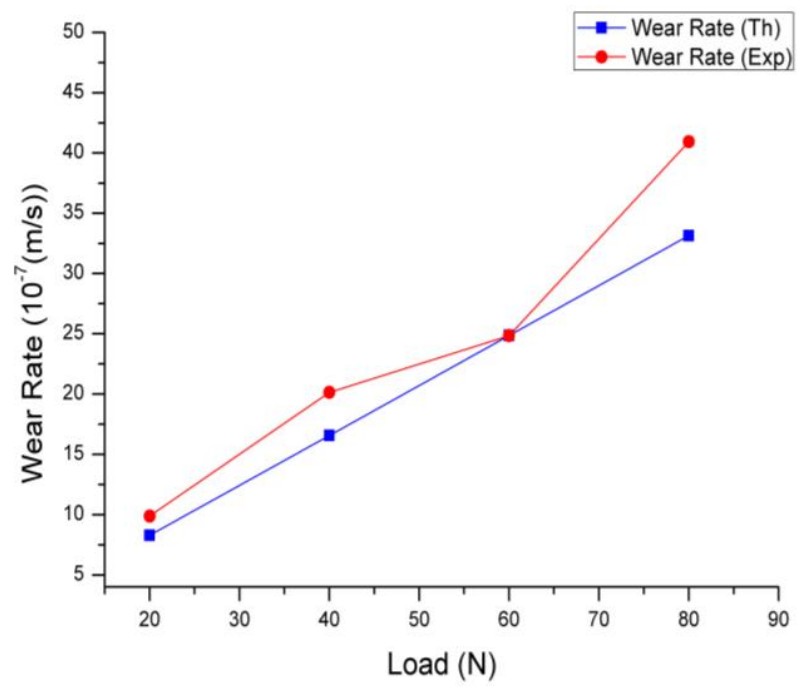

(i) $1100 \mathrm{rpm}$

Fig. 6. Wear rate $(\mathrm{m} / \mathrm{s})$ of the brake pad with load $(\mathrm{N})$ at constant sliding speed (rpm).

\subsection{Influence of temperature rise on wear rate of brake surface at constant sliding speed}

The influence of temperature rise on wear performance of brake pad friction material subjected to constant sliding speed is presented in Figs. 7a-7i. The surface temperature distribution is non-uniform at the pad and disc interface due to influence of frictional heat. The temperature distribution inside the friction interface is depends on the thermo-physical properties from the friction material. At 300 rpm sliding speed, the wear rate indicates the non-linear pattern as the temperature rises at start and it becomes linear after sometime by increase in temperature gradient up to $64{ }^{\circ} \mathrm{C}$ as shown in Fig. 7a. At low interface temperature, small debris, hard asperities and piece shape particles are present on the contact interface. The temperature rise due to frictional heat causes the change in surface microstructure and phase transformation of friction material, which will affect the interface lubrication formed due to friction film and changes the contact interface from boundary to dry friction. The theoretical and measured wear becomes slightly linear at $400 \mathrm{rpm}$ and $500 \mathrm{rpm}$ as temperature gradient changes to $141{ }^{\circ} \mathrm{C}$ and $150{ }^{\circ} \mathrm{C}$ indicated in Figs. $7 \mathrm{~b}$ and $7 \mathrm{c}$. 
Further increase in temperature increases the wear rate non-uniformly at $600 \mathrm{rpm}$ and 700 rpm and having much variation in theoretical and measured experimental wear rate values at $158{ }^{\circ} \mathrm{C}$ and $176{ }^{\circ} \mathrm{C}$ are shown in Figs. $7 \mathrm{~d}$ and $7 \mathrm{e}$. The rise in temperature is softened the metal matrix of friction material and charred to lose its bonding strength. Reinforced fibers from matrix are pulled and escaped to form the friction film on friction surface. These formed friction films are create interface lubrication phenomenon, which causes the resistance to wear of friction material. Wear rate of pad material at $800 \mathrm{rpm}$ and $900 \mathrm{rpm}$ is linear in nature and theoretical and experimental values are coincides with each other presented in Figs. 7f and 7g. The wear rate of pad material increases significantly as the temperature gradient changes considerably from $239{ }^{\circ} \mathrm{C}$ to $253{ }^{\circ} \mathrm{C}$ at 1000 rpm and $1100 \mathrm{rpm}$ resp. indicated in Figs. $7 \mathrm{~h}$ and $7 \mathrm{i}$. The wear is more severe at higher interface temperatures and decreases the strength and life of pad friction material.

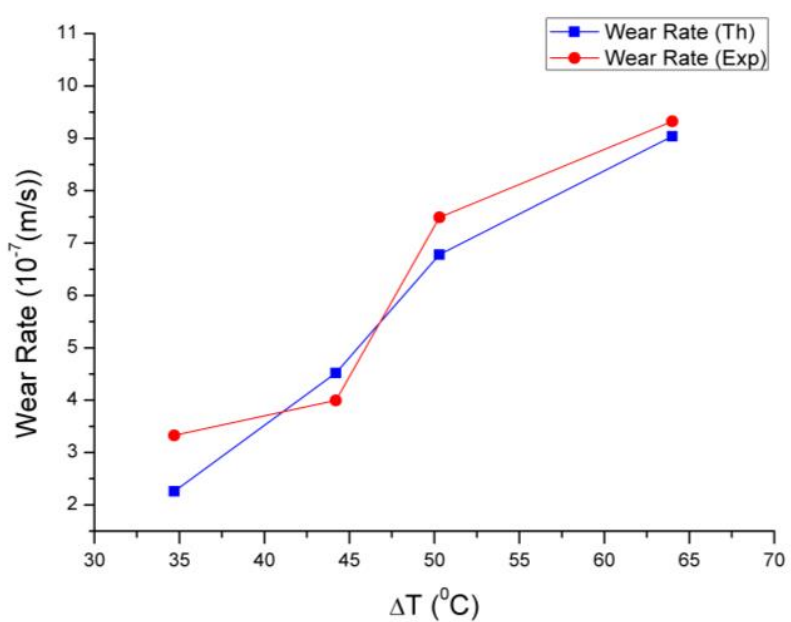

(a) $300 \mathrm{rpm}$

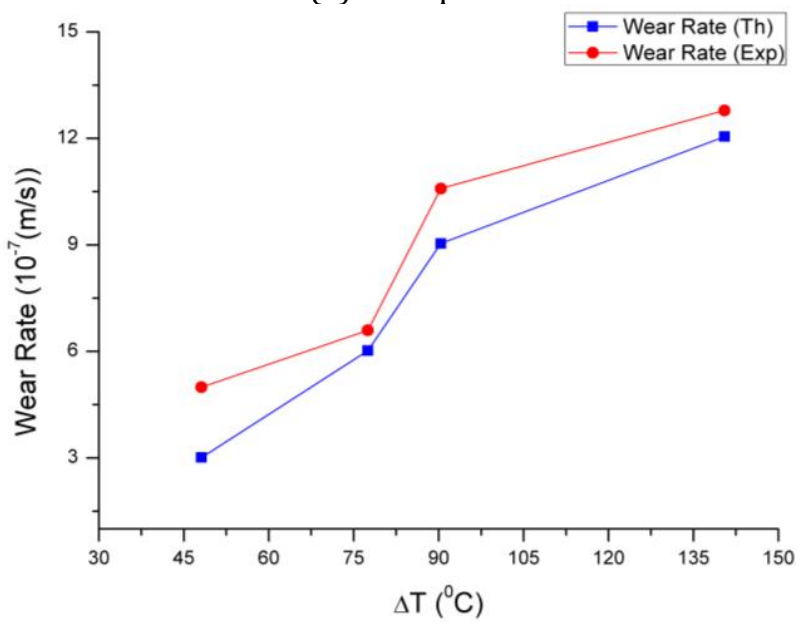

(b) $400 \mathrm{rpm}$

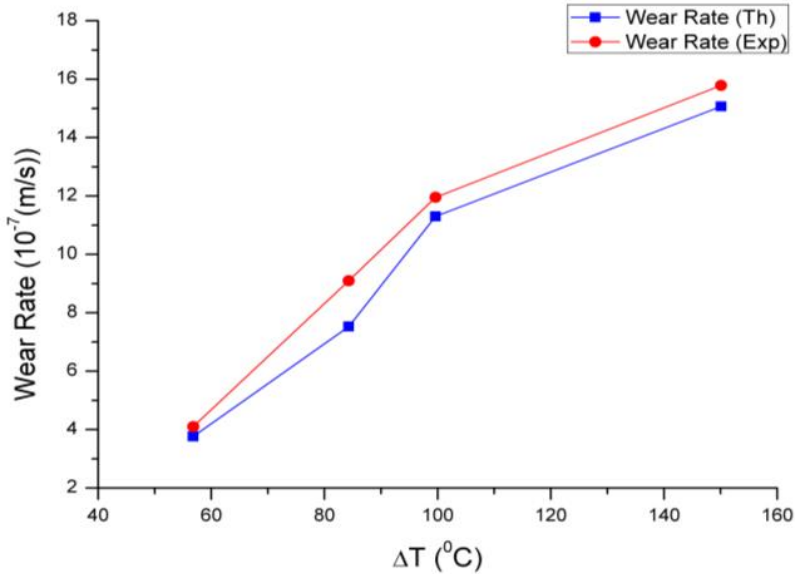

(c) $500 \mathrm{rpm}$

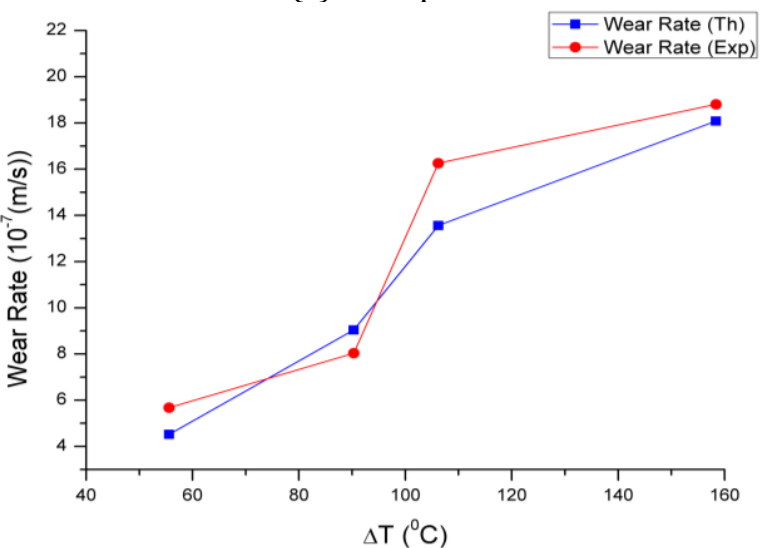

(d) $600 \mathrm{rpm}$

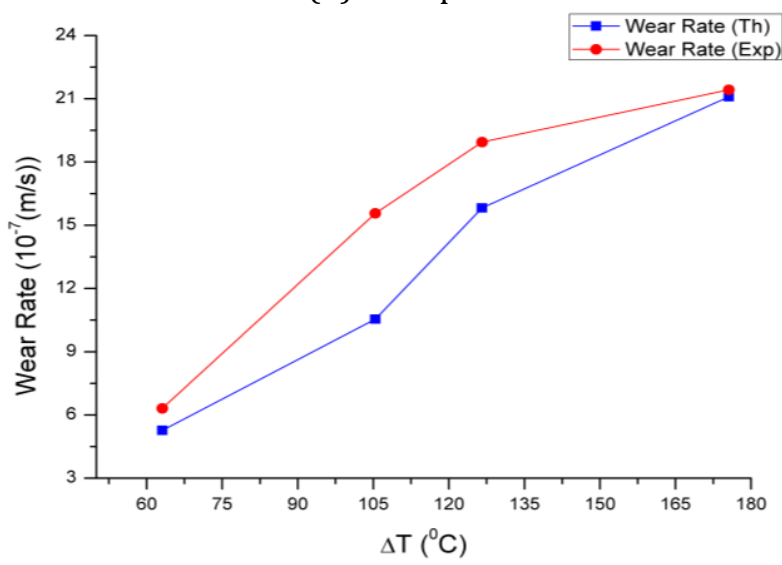

(e) $700 \mathrm{rpm}$

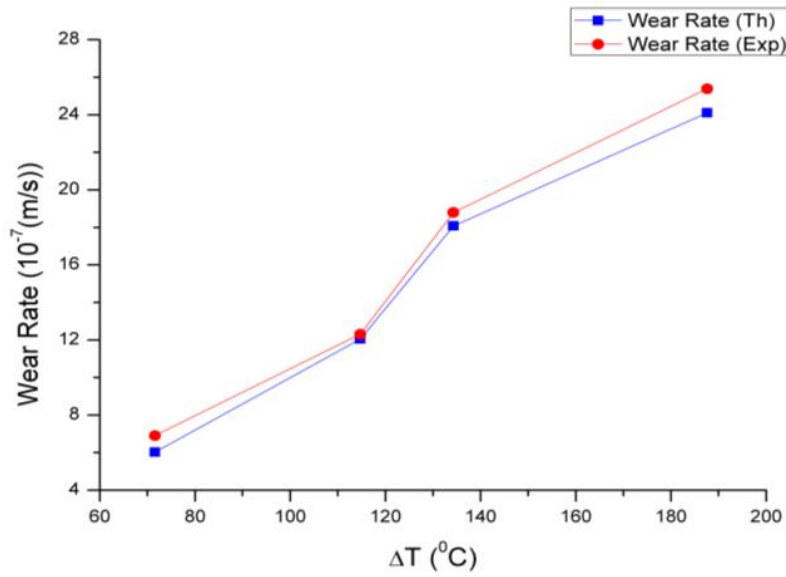

(f) $800 \mathrm{rpm}$ 


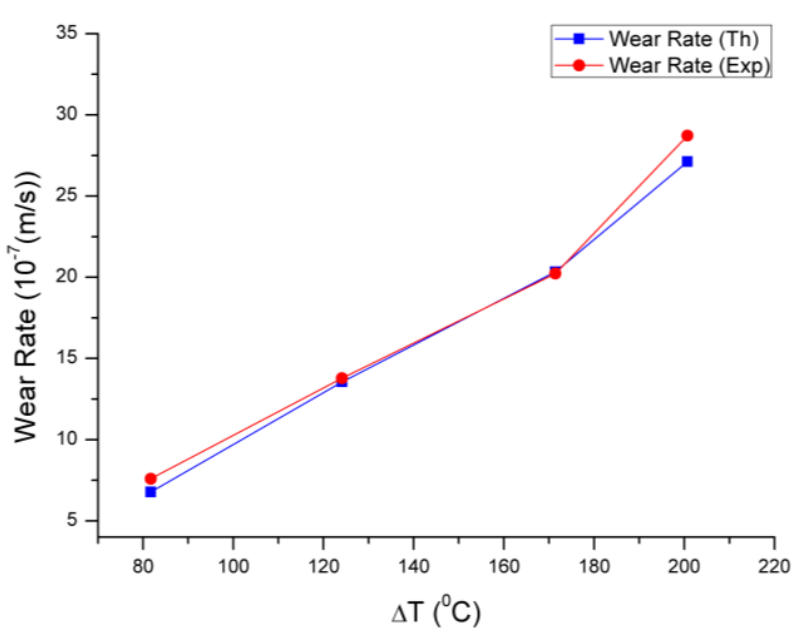

(g) $900 \mathrm{rpm}$

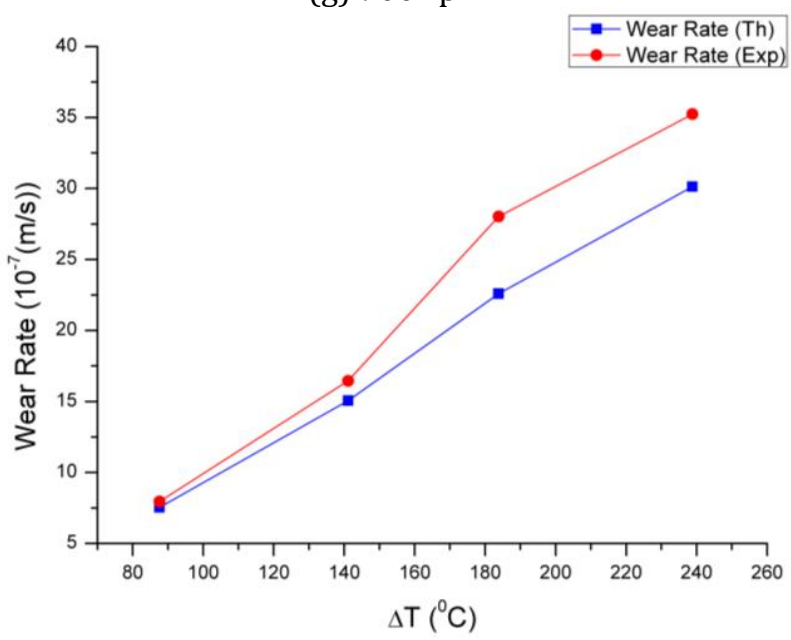

(h) $1000 \mathrm{rpm}$

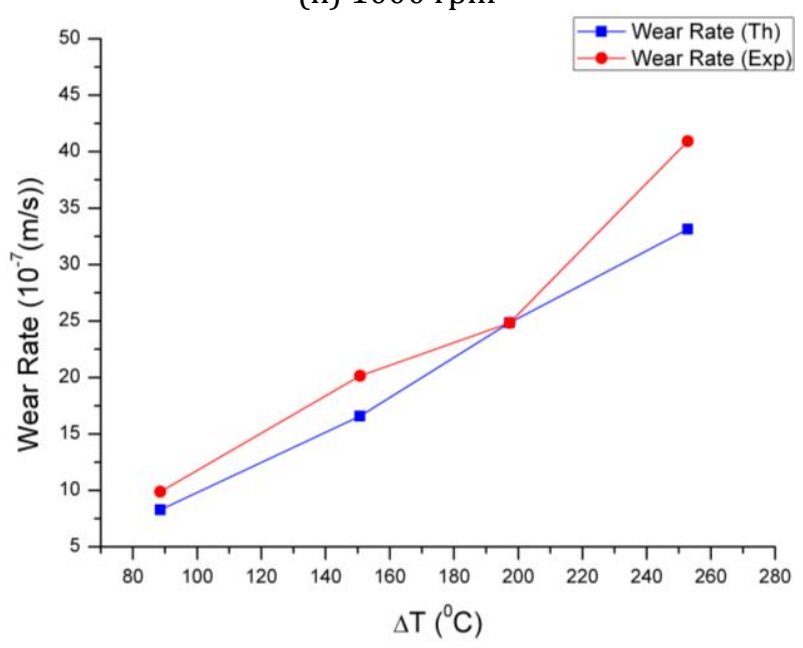

(i) $1100 \mathrm{rpm}$

Fig. 7. Wear rate $(\mathrm{m} / \mathrm{s})$ of the brake pad with temperature gradients $(\Delta \mathrm{T})$ at constant sliding speed (rpm).

\subsection{Influence of sliding speed on wear rate of braking surface at constant load}

The sliding speed is having a greater influence on tribological properties of the pad friction material. The sliding speeds have a greater influence on frictional heat, frictional and wear strength, and surface structure of friction material. It can be found that at low load with increase in sliding speed, the experimental wear rate firstly increases. After the speed grasps certain value, the wear rate decreases and finally increases linearly. At $20 \mathrm{~N}$ load, wear rate increases first from $300 \mathrm{rpm}$ to 400 rpm after $400 \mathrm{rpm}$ the wear rate decreases up to $500 \mathrm{rpm}$ and after $500 \mathrm{rpm}$ in increases gradually and linearly as shown in Fig. 8a. The wear behavior of frictional material at different sliding speeds is mainly depending on the interface temperature of friction surface. Under low load and speed, the friction films until have no longer formed and the absorbed moisture and oxygen lubricate the friction contact interface causes the low rate of wear. The increase in sliding speed, more asperities were deformed, shorn and fractured from the friction surface of pads. The asperities detached were trapped between the sliding surfaces, which causes high resistance to relative motion and rises the temperature between sliding surfaces. The increase in sliding speeds having a nonlinear trend of increase in wear rate for $40 \mathrm{~N}$ and $60 \mathrm{~N}$ loads presented in Figs. 8b and 8c. While further increase in sliding speeds at high load, temperature rise takes place. The rise in temperature formulates the friction film at interface. At $80 \mathrm{~N}$ loads, wear of friction material increases linearly and rapidly as shown in Fig. 8d. The temperature rise due to increase in sliding speed is amply high for thermal decomposition of surface material, which will results rapid increase in wear rate.

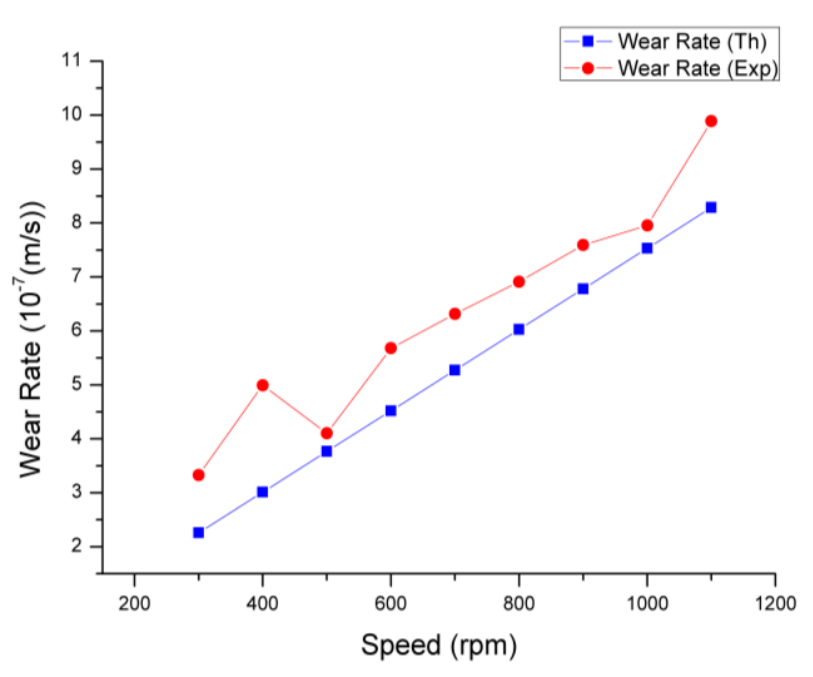

(a) $20 \mathrm{~N}$ 


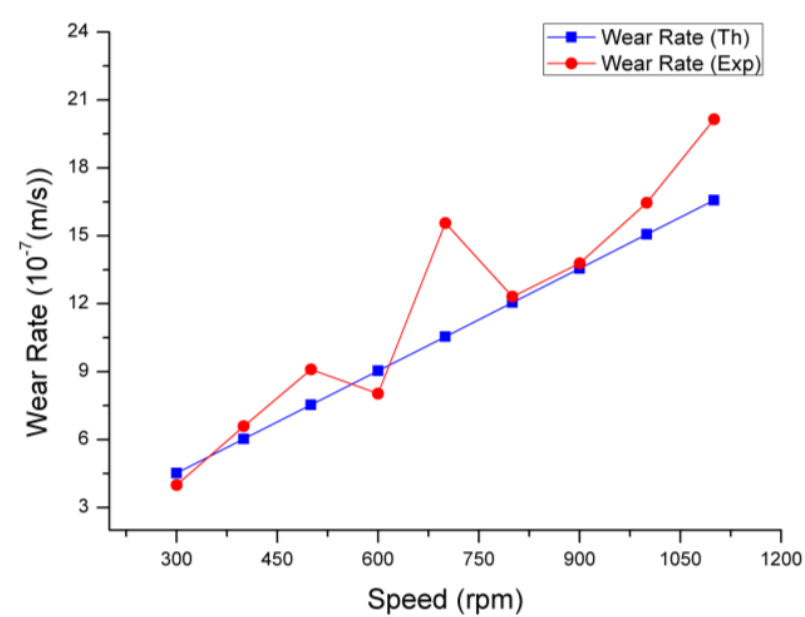

(b) $40 \mathrm{~N}$

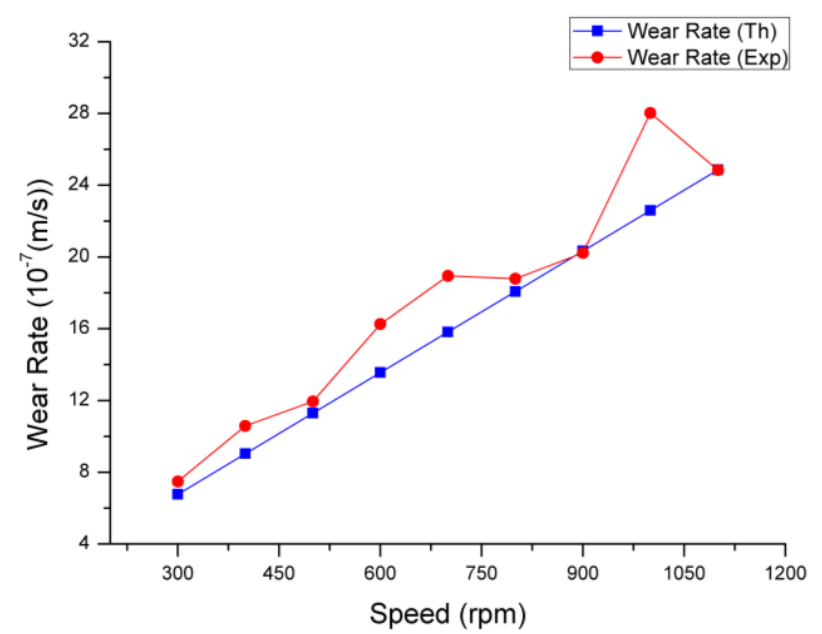

(c) $60 \mathrm{~N}$

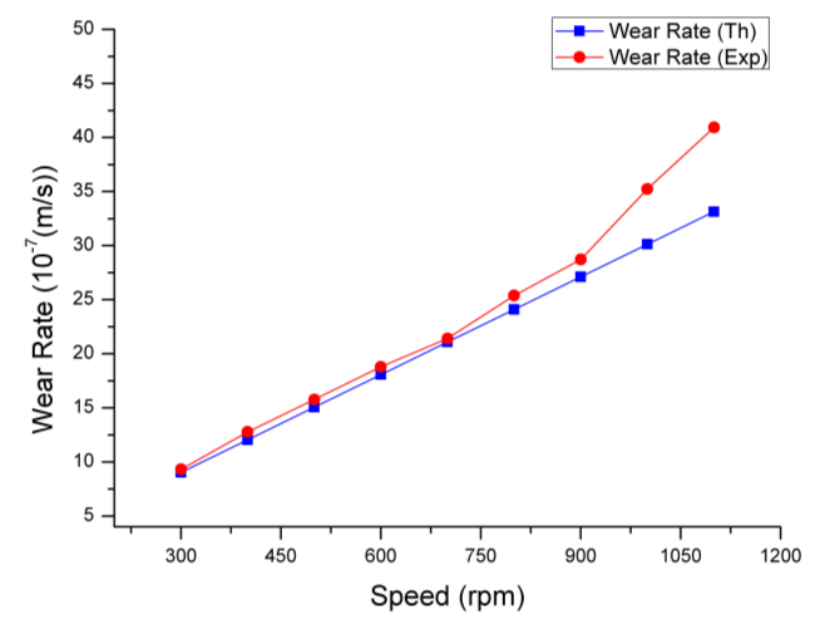

(d) $80 \mathrm{~N}$

Fig. 8. Wear rate $(\mathrm{m} / \mathrm{s})$ of the brake pad with Sliding Speeds (rpm) at constant load (N).

\subsection{Influence of temperature rise on wear rate of braking surface at constant load}

The temperature rise having significant influence on wear rate of brake pad friction material at constant load presented in Figs. 9a-
$9 \mathrm{~d}$. The wear at $20 \mathrm{~N}, 40 \mathrm{~N}$ and $60 \mathrm{~N}$ represents the non-linear trend of increase in wear rate due to influence of asperities present between contact surface interfaces is shown in Figs. 9a9c. At low temperature gradient, the primary plateaus serve as obstructions to the motion of finer friction surface particles and tend to stop these barriers to interface. After increase in temperature, these particles start to stick together to form the secondary contact plateaus. The formation of friction film is creating boundary lubrication phenomenon, which causes the resistance to wear of friction material. Maximum temperature gradient is indicate at $80 \mathrm{~N}$ load and wear rate varies linearly and rapidly. The theoretical and experimental values are coincides with each other as shown in Fig. 9d. The wear behavior of brake pad material is influenced by development of friction layer, compactness and thickness transformation and detachment with loosing of fragments and wear debris.

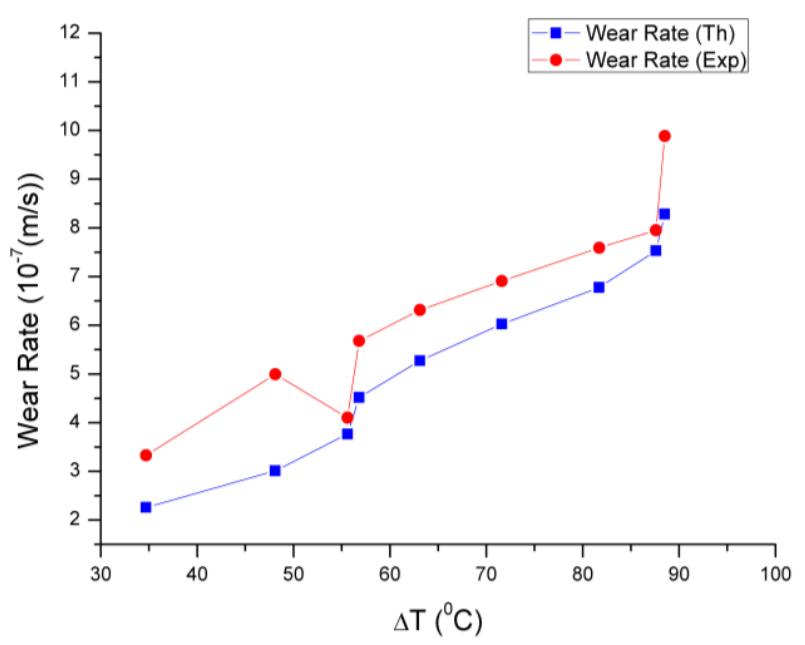

(a) $20 \mathrm{~N}$

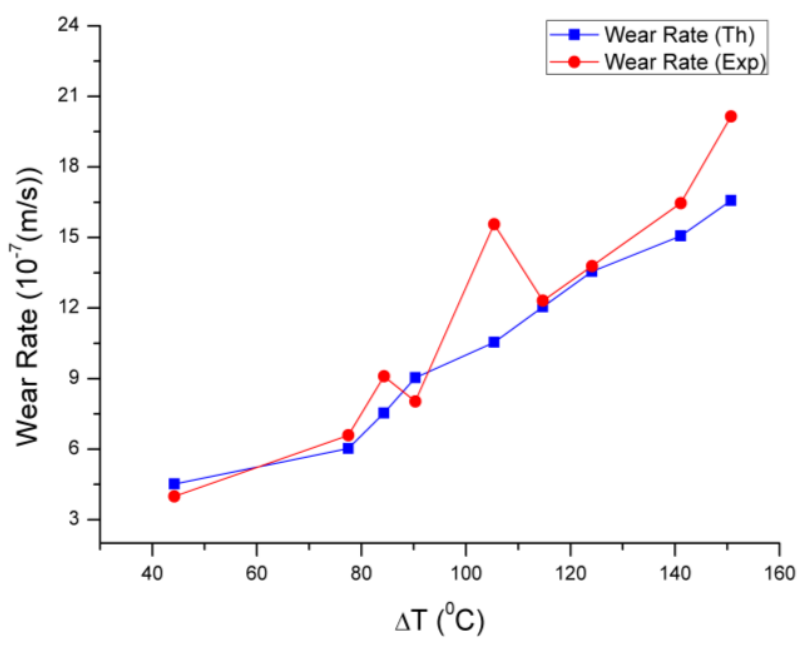

(b) $40 \mathrm{~N}$ 


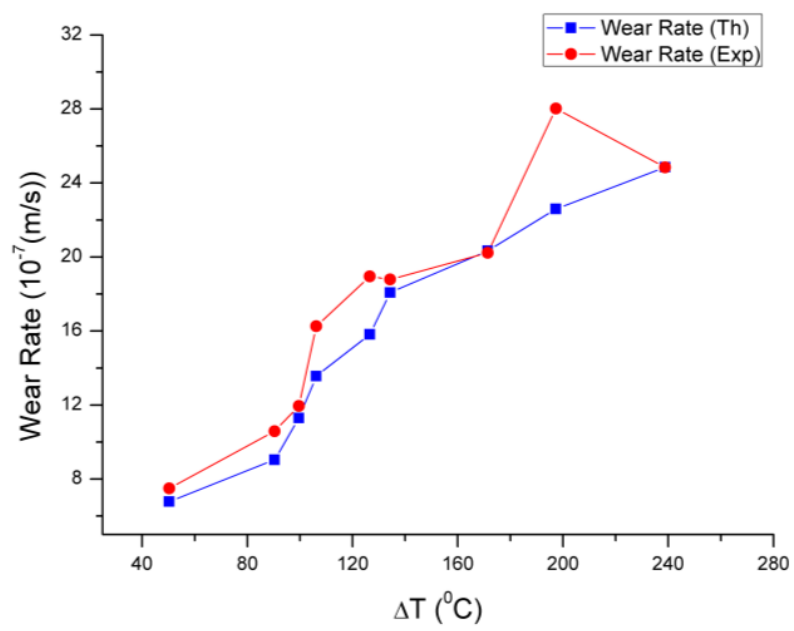

(c) $60 \mathrm{~N}$

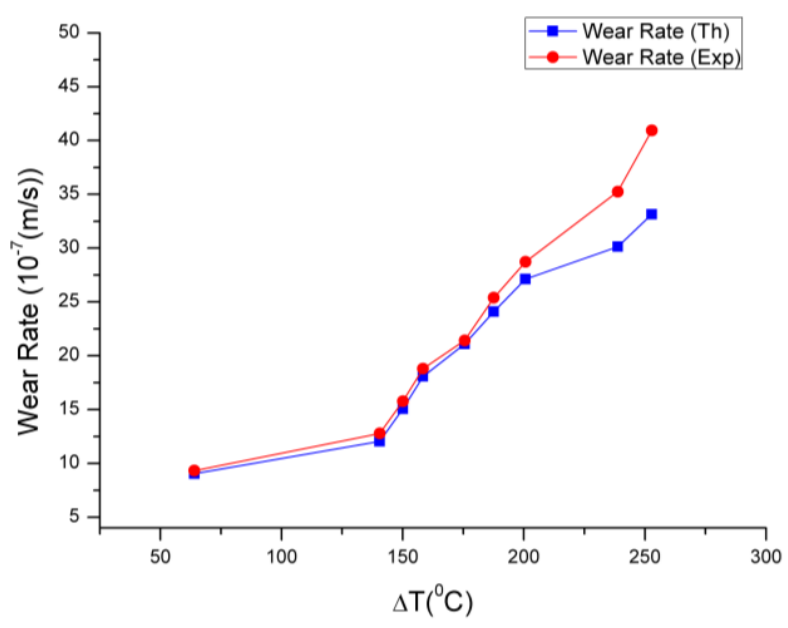

(d) $80 \mathrm{~N}$

Fig. 9. Wear rate $(\mathrm{m} / \mathrm{s})$ of the brake pad with temperature gradients $(\Delta \mathrm{T})$ at constant load $(\mathrm{N})$.

\section{CONCLUSIONS}

The friction and wear behavior of braking system are subjected to many factors like load, sliding speed, surface temperature and sliding distance along with time. The effect of brake operating conditions on temperature, coefficient of friction and wear rate of brake pad are tested at brake developed test rig under dry sliding conditions. The findings from this investigation can be summed up as follows:

- The coefficient of friction has an increasing trend under the effect of different loads and sliding speeds. The highest value for Coefficient of friction was 0.64 , showed at the $1000 \mathrm{rpm}$ speed and $60 \mathrm{~N}$ load. The friction behavior of pad surface intensely depends on the friction film layer formed at the contact interface and improves the frictional stability at high interface temperature.

- The increase in temperature gradient from $64{ }^{\circ} \mathrm{C}$ to $253{ }^{\circ} \mathrm{C}$ and contact interface temperature from $97.8^{\circ} \mathrm{C}$ to $306.7^{\circ} \mathrm{C}$, wear of friction surface becomes mild to severe. The increase in contact interface temperature causes low debris retention and low friction film formation time, which exhibits more removal of material from brake pad friction surface.

- The load and sliding speed directly affects the contact between the friction surface, which increases the contact temperature and material removal rate of friction material. The wear rate showed trend of slightly increase, then decrease and finally increases rapidly and linearly with increase in load and speed.

- The developed brake test rig can be effectively used to assess the friction and wear behavior of different brake pads for various operating conditions. This test rig also reduces the time required for calculating the coefficient of friction and wear rate.

- The analytical values are consistent with experimental observations and can be used for estimation of wear rate from extreme brake fading phenomenon.

\section{Acknowledgement}

The authors would like to thank Technical Education Quality Improvement Program (TEQIPIII), VJTI for providing the financial support.

\section{REFERENCES}

[1] M.H. Cho, S.J. Kim, R.H Basch, J.W. Fash, H. Jang. Tribological study of gray cast iron with automotive brake linings: The effect of rotor microstructure, Tribology International, vol. 36, iss. 7, pp. 537-545, 2003, doi: 10.1016/S0301679X(02)00260-8

[2] D.S. Chan, G.W. Stachowiak, Review of automotive brake friction materials, Proceedings of the Institution of Mechanical Engineers, Part D, Journal of Automobile Engineering, vol. 218, iss. 9, pp. 953-966, 2004, doi: 10.1243/0954407041856773 
[3] G.P. Ostermeyer, M. Muller, Dynamic interaction of friction and surface topography in brake systems, Tribology International, vol. 39, iss. 5, pp. 370-380, 2006, doi: 10.1016/j.triboint. 2005.04.018

[4] M. Godet, Third-bodies in tribology, Wear, vol. 136, iss. 1, pp. 29-45, 1990, doi: 10.1016/00431648 (90)90070-Q

[5] W. Osterle, I. Dorfel, C. Prietzel, H. Rooch, A.L. Cristol-Bulthe, G. Degallaix, Y. Desplanques, $A$ comprehensive microscopic study of third body formation at the interface between a brake pad and brake disc during the final stage of a pin-ondisc test, Wear, vol. 267, iss. 5-8, pp. 781-788, 2009, doi: 10.1016/j.wear.2008.11.023

[6] M. Eriksson, S. Jacobson, Tribological surfaces of organic brake pads, Tribology International, vol. 33, iss. 12, pp. 817-827, 2000, doi: 10.1016/S0301-679X(00)00127-4

[7] W. Osterle, M. Griepentrog, T. Gross, I. Urban, Chemical and microstructural changes induced by friction and wear of brakes, Wear, vol. 251, iss. 1-12, pp. 1469-1476, 2001, doi: 10.1016/S0043-1648(01)00785-2

[8] P.C. Verma, L. Menapace, A. Bonfanti, R. Ciudin, S. Gialanella, G. Straffelini, Braking pad-disc system, wear mechanisms and formation of wear fragments, Wear, vol. 322-323, pp. 251-258, 2015, doi: 10.1016/j.wear.2014.11.019

[9] M.H. Cho, K.H. Cho, S.J. Kim, D.H. Kim, H. Jang, The role of transfer layers on friction characteristics in the sliding interface between friction materials against gray iron brake disks, Tribology Letters, vol. 20, iss. 2, pp. 101-108, 2005, doi: 10.1007/s11249-005-8299-6

[10] G. Riva, G. Perricone, J. Wahlstrom, Simulation of Contact Area and Pressure Dependence of Initial Surface Roughness for Cermet-Coated Discs Used in Disc Brakes, Tribology in Industry, vol. 41, no. 1, pp. 1-13, 2019, doi: 10.24874/ti.2019.41.01.01

[11] B. Jiusheng, Z. Zhencai, Y. Yan, C. Guoan, Influence of initial braking velocity and braking frequency on tribological performance of non-asbestos brake shoe, Industrial Lubrication and Tribology, vol. 61, no. 6, pp. 332-338, 2009, doi: 10.1108/00368-790910988453

[12] J. Bao, Y. Yin, Z. Zhu, M. Tong, Y. Lu, Y. Peng, Wear modalities and mechanisms of the mining non-asbestos composite brake material, Applied Composite Materials, vol. 20, pp. 331-339, 2013, doi: $10.1007 / s 10443-012-9269-4$

[13] J. Bao, Z. Zhu, M. Tong, Y. Yin, Dynamic friction heat model for disc brake during emergency braking, Advanced Science Letters, vol. 4, no. 11-12, pp. 3716-3720, 2011, doi: 10.1166/asl.2011. 1882

[14] P.C. Verma, C. Rodica, B. Andrea, A. Pranesh, S. Giovanni, G. Stefano, Role of the friction layer in the high-temp. pin-on-disc study of a brake material, Wear, vol. 346-347, pp. 56-65, 2016, doi: 10.1016/j.wear.2015.11.004

[15] K. Lee, J.R. Barber, An experimental investigation of frictionally-excited thermoelastic instability in automotive disk brakes under a drag brake application, Journal of Tribology, vol. 116, iss. 3, pp. 409-414, 1994, doi: 10.1115/1.2928855

[16] P.J. Blau, B.C. Jolly, Wear of truck brake lining materials using three different test methods, Wear 259, iss. 7-12, pp. 1022-1030, 2005, doi: 10.1016/j.wear.2004.12.022

[17] P.J. Blau, B.C. Jolly, J. Qu, W.H. Peter, C.A. Blue, Tribological investigation of titanium-based materials for brakes, Wear, vol. 263, iss. 7-12, pp. 1202-1211, 2007, doi: 10.1016/j.wear.2006.12.015

[18] K.W. Liew, U. Nirmal, Frictional performance evaluation of newly designed brake pad materials, Materials \& Design, vol. 48, pp. 25-33, 2013, doi: 10.1016/j.matdes.2012.07.055

[19] B. Zhou, S. Li, Prediction and factor analysis for friction and wear performance of brake disk, Iranian Journal of Science and Technology, Transactions of Mechanical Engineering, vol. 43, pp. 245-252, 2019, doi: 10.1007/s40997017-0124-y

[20] P.D. Neis, N.F. Ferreira, F.P. Da Silva, Comparison between methods for measuring wear in brake friction materials, Wear, vol. 319, iss. 1-2, pp. 191-199, 2014, doi: 10.1016/j.wear.2014.08.004

[21] M. Federici, S. Gialanella, M. Leonardi, G. Perricone, G. Straffelini, A preliminary investigation on the use of the pin-on-disc test to simulate off-brake friction and wear characteristics of friction materials, Wear, vol. 410-411, pp. 202-209, 2018, doi: 10.1016/j.wear.2018.07.011

[22] J. Bros, S.F. Scieszka, The investigation of factors influencing dry friction in brakes, Wear, vol. 41, iss. 2, pp. 271-286, 1977, doi: 10.1016/00431648(77)90007-2

[23] X. Xiao, Y. Yin, J. Bao, L. Lu, X. Feng, Review on the friction and wear of brake materials, Advances in Mechanical Engineering, vol. 8, iss. 5, pp. 01-10, 2016, doi: 10.1177/1687814016647300 
[24] A.K. Ilanko, S. Vijayaraghavan, Wear behavior of asbestos-free eco-friendly composites for automobile brake materials, Friction, vol. 4, pp. 144-152, 2016, doi: 10.1007/s40544-016-0111-0

[25] N.S.M.E. El-Tayeb, K.W. Liew, On the dry and wet sliding performance of potentially new frictional brake pad materials for automotive industry, Wear, vol. 266, iss. 1-2, pp. 275-287, 2009, doi: 10.1016/j.wear.2008.07.003

[26] B.S. Rajan, M.S. Balaji, C. Velmurugan, Correlation of field and experimental test data of wear in heavy commercial vehicle brake liners, Friction, vol. 5, pp. 56-65, 2017, doi: 10.1007/s40544-017-0138-x

[27] B.S. Rajan, M.A. Balaji, K. Sathickbasha, P. Hariharasakthisudan, Influence of Binder on Thermomechanical and Tribological Performance in Brake Pad, Tribology in Industry, vol. 40, no. 4, pp. 654-669, 2018, doi: 10.24874/ti.2018.40.04.12

[28] S. Fan, L. Zhang, L. Cheng, J. Zhang, S. Yang, H. Liu, Wear mechanisms of the C/SiC brake materials, Tribology International, vol. 44, iss. 1, pp. 25-28, 2011, doi: 10.1016/j.triboint.2010.09.003

[29] C. Menapace, A. Mancini, M. Federici, G. Straffelini, S. Gialanella, Characterization of airborne wear debris produced by brake pads pressed against HVOF-coated discs, Friction, vol. 8, pp. 421-432, 2020, doi: 10.1007/s40544-019-0284-4

[30] J. Wahlstrom, A comparison of measured and simulated friction, wear, and particle emission of disc brakes, Tribology International, vol. 92, pp. 503-511, 2015, doi: 10.1016/j.triboint.2015.07.036

[31] J.R. Laguna-Camacho, G. Juarez-Morales, C. Calderon-Ramon, V. Velazquez-Martinez, I. Hernandez-Romero, J.V. Mendez-Mendez, M. Vite-Torres, A study of the wear mechanisms of disk and shoe brake pads, Engineering Failure Analysis, vol. 56, pp. 348-359, 2015, doi: 10.1016/ j.engfailanal.2015.01.004

[32] A. Belhocine, A.R. Abu Bakar, M. Bouchetara, Numerical Modeling of Disc Brake System in Frictional Contact, Tribology in Industry, vol. 36, no. 1, pp. 49-66, 2014.

[33] R.G. Bayer, W.C. Clinton, C.W. Nelson, R.A. Schumacher, Engineering model for wear, Wear, vol. 5, iss. 5, pp. 378-391, 1962, doi: 10.1016/0043-1648(62)90075-3

[34] H.C. Meng, K.C. Ludema, Wear models and predictive equations: their form and content, Wear, vol. 181-183, pp. 443-457, 1995, doi: 10.1016/0043-1648(95)90158-2
[35] J.A. Williams, Wear modelling: analytical, computational and mapping: a continuum mechanics approach, Wear, vol. 225-229, pp. 117, 1999, doi: 10.1016/S0043-1648(99)00060-5

[36] Z. Barecki, S.F. Scieszka, Computer simulation of the lining wear process in friction brakes, Wear, vol. 127, iss. 3, pp. 283-305, 1988, doi: 10.1016/0043-1648(88)90161-5

[37] J.F. Archard, Contact and rubbing of flat surfaces, Journal of applied physics, vol. 24, iss. 8, pp. 981-988, 1953, doi: 10.1063/1.1721448

[38] S.K. Rhee, Wear equation for polymers sliding against metal surfaces, Wear, vol. 16, iss. 6, pp. 431445, 1970, doi: 10.1016/0043-1648 (70)90170-5

[39] H.P. Khairnar, V.M. Phalle, S.S. Mantha, Estimation of automotive brake drum-shoe interface friction coefficient under varying conditions of longitudinal forces using Simulink, Friction, vol. 3, pp. 214-27, 2015, doi: 10.1007/s40544-015-0082-6

[40] S.S. Mantha, H.P. Khairnar, V.M. Phalle, Comparative Frictional Analysis of Automobile Drum and Disc Brakes, Tribology in Industry, vol. 38, no. 1, pp. 11-23, 2016.

[41] A.V. Chichinadze, Calculation and investigation of external friction during braking, Moscow, Nauka, vol. 3, 1967.

[42] J. Awrejcewicz, D. Grzelczyk, Applicability of a hereditary integral wear model with exponential kernel memory function in a friction connection of elastic shields of a friction clutch, International Journal of Applied Mechanics and Engineering, vol. 15, no. 3, pp. 609-617, 2010.

[43] J. Awrejcewicz, D. Grzelczyk, Modeling and analytical/numerical analysis of wear processes in a mechanical friction clutch, International Journal of Bifurcation and Chaos, vol. 21, no. 10, pp. 2861-2869, 2011, doi: org/10.1142/S02181-27411030192

[44] M.V. Gavrikov, R.L. Mazing, The hereditary-ageing model of wear and its application to problems with monotonically increasing contact zone, Treniye i Iznos, vol. 9, no. 2, pp. 274-279, 1988.

[45] I. Paczelt, Z. Mroz, Numerical analysis of steady thermo-elastic wear regimes induced by translating and rotating punches, Computers \& structures, vol. 89, iss. 23-24, pp. 2495-2521, 2011, doi: 10.1016/j.compstruc.2011.06.001

[46] H. Czichos, T. Saito, Springer Handbook of Materials Measurement Methods, L. Smith, Springer, Berlin, vol. 978, pp. 701-709, 2006, doi: 10.1007/978-3-540-30300-8 


\section{NOMENCLATURE}

k: Stiffness coefficient.

$K_{(w)}:$ Wear coefficient $\left(\mathrm{m}^{3} / \mathrm{Nm}\right)$.

$P(r, t)$ : Change in braking pressure (bar).

$\alpha_{1}, \beta_{1}, \beta_{2}$ : empirical constants

$\omega(t)$ : Change in angular velocity with time (rad/s)
$\mathrm{F}(\mathrm{t})$ : Applied contact force $(\mathrm{N})$.

$\frac{\partial U_{(w)}}{\partial t}:$ Wear rate with respect to time $(\mathrm{m} / \mathrm{s})$

$\mathrm{r}_{\mathrm{i}}, \mathrm{r}_{\mathrm{o}}$ : Inner and outer radius of brake pad resp. (m).

$\theta_{1} \& \theta_{2}$ : Inner and outer angle of brake pad (rad).

$\Delta T$ : Temp. rise at brake contact interface $\left({ }^{\circ} \mathrm{C}\right)$. 